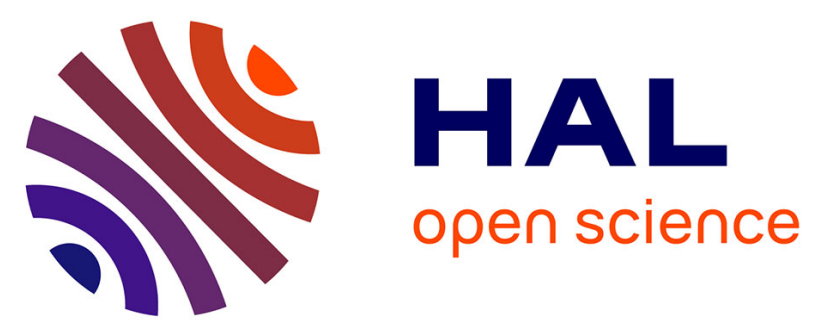

\title{
Lower-Middle Jurassic facies patterns in the NW Afghan-Tajik Basin of southern Uzbekistan and their geodynamic context
}

Franz T. Fürsich, Marie-Françoise Brunet, Jean-Luc Auxiètre, Hermann

Munsch

\section{To cite this version:}

Franz T. Fürsich, Marie-Françoise Brunet, Jean-Luc Auxiètre, Hermann Munsch. Lower-Middle Jurassic facies patterns in the NW Afghan-Tajik Basin of southern Uzbekistan and their geodynamic context. Geological Society Special Publication, 2017, In: Brunet, M.-F., McCann, T. \& Sobel, E. R. (eds) Geological Evolution of Central Asian Basins and the Western Tien Shan Range, 427, pp.SP427.9. 10.1144/SP427.9 . hal-01206129

\section{HAL Id: hal-01206129 \\ https://hal.science/hal-01206129}

Submitted on 29 Sep 2015

HAL is a multi-disciplinary open access archive for the deposit and dissemination of scientific research documents, whether they are published or not. The documents may come from teaching and research institutions in France or abroad, or from public or private research centers.
L'archive ouverte pluridisciplinaire HAL, est destinée au dépôt et à la diffusion de documents scientifiques de niveau recherche, publiés ou non, émanant des établissements d'enseignement et de recherche français ou étrangers, des laboratoires publics ou privés. 
17 abbreviated title: Jurassic facies patterns Afghan-Tajik Basin 
Abstract: Based on eleven sections, the palaeoenvironments and depositional history of the northwestern Afghan-Tajik Basin in southern Uzbekistan have been reconstructed for the time interval Early Jurassic to Early Callovian. The earliest sediments, resting on Palaeozoic basement rocks, date from the Early Jurassic Period. Up to the end of the Early Bajocian time up to more than $500 \mathrm{~m}$ of non-marine sediments accumulated due to extensional tectonics inducing active subsidence. In the Late Bajocian time interval, transgression led to the establishment of siliciclastic ramps that were influenced by storm processes. After a condensed unit in the Middle Bathonian, sedimentation resumed in an outer carbonate ramp basinal setting as the subsidence rate outpaced the diminished siliciclastic sediment supply. The change from siliciclastic to carbonate sedimentation in the Middle Jurassic Period is thought to be multifactorial, reflecting levelling of relief in the hinterland, the subsidence moving to a thermally more quiet stage, and a change from humid to arid climatic conditions. These features are also observed in the area of present-day Iran. Similarly, the timing of the transgression coincides with that in eastern and northern Iran stressing the regional significance of this event.

After the collisions of the Cimmerian terranes with Eurasia in the Late Triassic (e.g., Stampfli \& Borel 2002; Barrier \& Vrielynck 2008; Wilmsen et al. 2009a; Zanchi et al. 2009, 2012) a number of new or re-activated sedimentary basins formed north of the collision zone in central Asia. Two of these basins are the Amu Darya Basin stretching across Turkmenistan and Uzbekistan and the Afghan-Tajik Basin extending across Uzbekistan, Tajikistan, and Afghanistan (e.g., Brookfield \& Hashmat 2001; Ulmishek 2004; Klett et al. 2006) (Fig. 1). These two basins had a very close evolution from the Late Palaeozoic onwards. During the Jurassic, the Amu Darya Basin was connected with the Afghan-Tajik Basin in the east (e.g., Ulmishek 2004). The important difference stems from Cenozoic shortening and indentation in the east due to the collision of India: The Pamirs evolution induced folding/thrusting of the sedimentary cover in the Afghan-Tajik Basin (Nikolaev 2002; Klett et al. 2006).

In the west, the Amu Darya Basin is bordered by the Kara Bogaz-Karakum High, in the south by the Kopet Dagh Foldbelt, and in the north by the Kyzyl Kum High (Ulmishek 2004). The Afghan-Tajik Basin is bordered to the north by the western part of the Tien Shan (the West Gissar), in the east by the Pamirs and in the south by the North Afghanistan High and Bande Turkestan Mountains (Klett et al. 2006; Montenat 2009; Siehl 201X). The southwestern Gissar range stretches southwesterly between the northern parts of the Amu 
Darya and Afghan-Tajik basins. Western and southwestern Gissar are the main areas where Jurassic sediments crop out and may be studied in the field. On the northern and southern margins of the Amu Darya and Afghan-Tajik basins they have been reached by wells. Sedimentation started in Permian-Triassic rift basins that formed in the folded and metamorphosed Palaeozoic basement. During the Jurassic Period the Amu Darya and AfghanTajik basins subsided very rapidly and became filled with a thick succession of siliciclastic (Lower and early Middle Jurassic), mixed carbonate-siliciclastic (Bathonian to Lower Callovian), carbonate (Middle Callovian-Kimmeridgian), and finally evaporitic (Kimmeridgian?-Tithonian) sediments. Due to their importance as hydrocarbon source and reservoir rocks (for summaries see Ulmishek 2004; Klett et al. 2006), the strata have been extensively studied since the Middle of the last century (e.g., Egamberdiev \& Ishniyazov 1990; Mitta 2001; D.P. Ishniyazov, pers. comm. 2011; V. Kharin, pers. comm. 2011; Tevelev \& Georgievskii 2012), but mainly from a stratigraphic point of view and often published in Russian journals or reports not easily available internationally. No detailed palaeoenvironmental analysis of these rocks exists, but in several review papers the evolution of these sedimentary basins has been briefly outlined, usually in context with their petroleum potential (e.g., Brookfield \& Hashmat 2001; Ulmishek 2004; Klett et al. 2006).

The aim of the present study is to provide a palaeoenvironmental reconstruction of the Lower and Middle Jurassic part of the basin fill in southern Uzbekistan, to relate the results to the palaeoclimatic and palaeotectonic setting, and to discuss the geodynamic framework governing the evolution of the basin. We do this with an integrated approach using, apart from sedimentological data, also biostratigraphic, ichnological, and taphonomic information.

\section{Material and methods}

Altogether, eleven sections in five areas were measured (Fig. 1, Table 1): two sections (Vandob, Shalkan) in the Kugitang Mountains of southern Uzbekistan close to the Turkmenistan border, one section at Panjab (northern Kugitang Mountains), two sections in the southeastern part of Uzbekistan close to the border to Tajikistan (Sangardak, Shargun), two sections in the southernmost part of the Gissar Mountains (Iron Gate, Dalut Mine), and four sections at Vuariz in the west-central part of the Gissar Mountains, ESE of Shahrisabsz (Fig. 1). Of these sections the Vandob, Shalkan, Shargun, and Sangardak sections span the complete succession from the basement to the base of the upper Middle Jurassic carbonate 
platform, with a thickness between 335 and $920 \mathrm{~m}$. In the remaining sections either the base or the transition to the Upper Jurassic carbonates is missing. Strictly speaking the study area forms the western margin of the Afghan-Tajik Basin, but during the Jurassic the Amu Darya and Afghan-Tajik basins formed a single unit.

Field data were collected in the course of five field trips to the area in the years 2010, 2011, 2013, and 2014. Sections were logged in detail, bed by bed wherever possible, but in some sections part of the fine-grained succession, consisting of argillaceous silt or silty marl, was overgrown or deeply weathered and could be measured only cursorily. Data retrieval involved recording of lithology, sedimentary structures, trace fossils, body fossils, and taphonomic features. Laboratory work involved analysis of thin-sections and preparation and identification of body fossils.

\section{Litho-, bio- and chronostratigraphy}

\section{Lithostratigraphy}

Several lithostratigraphic frameworks exist for the Jurassic succession in southern Uzbekistan, which is best developed in the Kugitang Mountains. Here, we follow the classification in Krymholts et al. (1988), who subdivided the Jurassic succession into seven formations (Fig. 2). The succession starts with the Hettangian Pliensbachian (possibly also lowermost Toarcian) Sandzhar Formation (also called Sanjar Formation; continental conglomerates, breccias, red mudstones and siltstones; Resolutions 1977), which is only locally present and apparently constitutes the fill of rifts and small basins developed at the top of the underlying basement. It was not encountered in the investigated area. The overlying Gurud Formation, again a non-marine siliciclastic unit, represents fluvial to lacustrine environments with local development of coal deposits. It comprises the time span Toarcian to early Bajocian. The Gurud Formation, 290 to 450 m thick in the Kugitang Mountains, is overlain by the marginal- to shallow-marine siliciclastic to mixed carbonate-siliciclastic, Upper Bajocian Lower Bathonian Degibadam Formation $(\sim 200 \mathrm{~m})$, characterized by argillaceous silt, silt, and sandstones with occasional marine fossils (ammonites, bivalves). The overlying Lower Bathonian Tangiduval Formation $(\sim 30-80 \mathrm{~m})$ is difficult to differentiate from the Degibadam Formation, the major difference being a greater carbonate content in form of silty marl and calcareous and/or bioclastic sandstones. The carbonate and fossil 
content increases gradually so that the boundary between the two formations is somewhat arbitrary. This is particularly true of the sections at Sangardak and Shargun. Carbonate

130 sediments (lime mudstones, marl, and subordinate bioclastic and oncolitic floatstones)

131 characterize the following Baysun Formation (50-225 m). According to the literature (e.g.,

132 Krymholts et al. 1988), the formation starts in the Late Bathonian, but based on ammonite

133 finds the base is here regarded still Middle Bathonian, the top extending to the Lower

134 Callovian. The succession continues with thick-bedded carbonates of the Middle Callovian -

135 Kimmeridgian Kugitang Formation, followed by anhydrites, dolostones, limestones, and salt

136 deposits of the Kimmeridgian - Tithonian Gaurdak Formation (approximately $1000 \mathrm{~m}$ ), and

137 by continental red beds of the Karabil Formation, the latter spanning the Jurassic-Cretaceous

138 boundary.

139 For the Middle Callovian Tithonian part of the succession in the northern part of the 140 Afghan-Tajik Basin and the Uzbekistan northern margin of the neighbouring Amu Darya

141 Basin a new, more elaborate classification scheme has been proposed, taking into account

142 lateral facies variations within the carbonate complex and a Tithonian age for the Gaurdak

143 evaporites (Abdullaev \& Mirkamalov 1998). As this part of the succession is not the subject

144 of the paper, we continue to use the term Kugitang Formation for the sake of simplicity.

Bio- and chronostratigraphy

The biostratigraphic zonation of the marine part of the sedimentary succession is based on ammonites, which have been investigated in great detail (e.g., Krymholts \& Zakharov 1971; Mitta 2001; Mitta \& Besnosov 2007). They allow a relatively detailed subdivision of the strata and can be used to define the ages of the lithostratigraphic units. Unfortunately, ammonites were found only sporadically in the field, thus only a rough correlation of sections,

154 based largely on lithological features, could be achieved. Finds of the ammonite Parkinsonia 155 parkinsoni near the base of the marine succession (Degibadam Formation) in the Iron Gate 156 section confirmed the Late Bajocian age of the transgression in the area (see also Krymholts 157 et al. 1988), and ammonites such as Procerites provided a Middle Bathonian age for the 158 condensed base of the Baysun Formation. As no age-diagnostic ammonites were recorded 159 from sections at Vuariz, Shargun, and Sangardak it cannot be evaluated whether, and if to 160 what extent, the marine transgression and the boundaries of the lithostratigraphic units are 161 diachronous. 

workers subdivided this part into stages based on macroscopic plant remains and pollen and spore assemblages (e.g., Gomolitzky \& Lobanova 1969; Renzhina \& Fokina 1978; for a summary see Vakhrameev et al. 1988). However, during our field work no well preserved plant remains were found that could have been used for dating the succession. The age assignments of the non-marine formations are therefore taken from Krymholts et al. (1988). on the basis of land plant associations and freshwater molluscs (Sandzhar and Gurud regional stages) or on ammonites (in ascending order Sarydiirmen, Baysun, Kugitang, and Gaurdak regional stages) (Krymholts et al. 1988).

\section{The sections}

In the following, the eleven sections are briefly described (for their precise position see Table 1). In the Kugitang Mountains two sections have been measured, one at Vandob, the other at Shalkan. In both cases the Jurassic rocks rest with angular unconformity on Palaeozoic metamorphic basement.

(1) Shalkan section (923 m; Figs. 3, 5a). - At Shalkan, these metamorphic rocks are overlain by up to $2 \mathrm{~m}$ of brown soil; clay with scattered gravel-sized rounded quartz grains and of poorly exposed silty clay. Four thick cross-bedded, conglomeratic to gravelly, coarse-grained sandstone units fining to medium-grained sandstones occur from $30-56 \mathrm{~m}$ and are followed by argillaceous silt with several carbonaceous levels and some fine-grained sandstone intercalations. The overlying, predominantly argillaceous-silty sediments with occasional thin sandstone interbeds are poorly exposed and contain some coal layers. From 375 to $394 \mathrm{~m}$ another conglomeratic to gravelly sandstone package is present. Up to $453 \mathrm{~m}$ it is overlain by

189 finer-grained coarsening-upward hemi-cycles. Apart from plant and wood fragments and 190 occasional rootlets no fossils are present. All these sediments belong to the non-marine Gurud

191 Formation. From 453 m onwards marine trace fossils and shell fragments occur and rare 192 ammonites indicate a Late Bajocian age of the rocks, which consist of silt alternating with 193 hummocky cross-stratified sandstones, arranged in thickening- and coarsening-upward cycles.

194 From 554 m onwards, the thickness of the sandstones increases and hummock cross-

195 stratification (HCS) is replaced by large-scale trough cross-stratification. Fine-grained units 
are commonly black and rarely carbonaceous. These rocks belong to the Degibadam

197 Formation. Its boundary with the overlying Tangiduval Formation has been drawn where

198 shell fragments, bivalves, and carbonate cement increase in abundance. A richly fossiliferous unit (729-733 m) with abundant ammonites and bivalves forms the base of the next stratigraphic unit, the Baysun Formation. The ammonites indicate a Middle Bathonian age of this condensed unit. The Baysun Formation is composed of silty marl, which is deeply weathered. It appears unfossiliferous, but fresh samples display numerous small infaunal bivalves preserved as internal moulds. Intercalated between the silty marl are nodular oncoidal float- to micritic rudstones. The boundary to the overlying carbonates of the Kugitang Formation is gradual.

(2) Vandob section (799 m; Fig. 6). - The Vandob section, situated $18 \mathrm{~km} \mathrm{SSW}$ of Shalkan, is very similar to the Shalkan section except that the coarse-grained conglomeratic sandstones rest directly on the deeply weathered metamorphic basement. Much of the argillaceous-silty part of the Gurud Formation is overgrown. The upper part of the Degibadam Formation and the Tangiduval Formation are organized in well developed coarsening-upward cycles. The condensed base of the Baysun Formation contains, as in the Shalkan section, numerous ammonites. The silty marl of the lower half of the formation gives way in the upper half to

214 nodular floatstones and marlstones. The find of the ammonite Macrocephalites two-thirds up 215 indicates an Early Callovian age.

(3) Panjab section (330 m; Fig. 7). - Situated $27 \mathrm{~km}$ northeast of Shalkan, the well exposed Panjab section starts in the middle of the Degibadam Formation. Except for differences in thickness the section mirrors those at Vandob and Shalkan. The upper part of the Baysun Formation displays hemi-cycles characterized by increasing carbonate content (marl to marlstone or wackestone). The Lower Callovian ammonite Macrocephalites occurs $130 \mathrm{~m}$ above the base of the formation.

(4) Dalut Mine section near the village of Toda (572 m; Fig. 8). - The incomplete section, situated $83 \mathrm{~km} \mathrm{SW}$ of the Shargun section and $35 \mathrm{~km} \mathrm{NE}$ of Panjab, has been measured on the northwestern limb of a large NE-SW trending anticline. At two levels the rocks are heavily folded and faulted and the recorded thickness probably contains some error. The base of the Jurassic succession is not exposed, but the 24-m-thick basal sandstone package (Fig. 9a) most 
has been observed. The thickness of the Gurud Formation is comparable to that of the

231 Kugitang sections. The formation is composed of an alternation of argillaceous silt,

232 sandstones, and thin coal layers. Root horizons are widespread and plant fragments are

233 ubiquitous. Only the lower $37 \mathrm{~m}$ of the marine Degibadam Formation could be measured. It is

234 characterised by alternations of argillaceous silt and fine-grained sandstone, the latter

235 displaying HCS or parallel-lamination followed by ripple lamination. The following part of

236 the section is too steep for measuring. Moreover it is disrupted by a major fault. The total

237 thickness of the Jurassic succession up to the Kugitang Formation is in the order of 900-950

$238 \mathrm{~m}$, taking into account information provided by the neighbouring Derbent section.

(5) Derbent (Iron Gate) section (411 m; Fig. 10). - The section north of Derbent at the so-

241 called Iron Gate, situated $9 \mathrm{~km} \mathrm{WNW}$ of the Dalut mine section, exposes the upper part of the

242 Jurassic succession. The section has been measured on the western flank of a deeply cut

243 valley which dissects a NE-SW trending anticline. The section starts close to the base of the

244 Degibadam Formation, which consists of fine-grained siliciclastics with thin sandstone

245 intercalations and a 45-m-thick sandstone package in the middle. The base of the Tangiduval

246 Formation has been placed at the first limestone bed. The formation is largely organised as

247 asymmetric coarsening-upward cycles. The top beds contain bivalves and ammonites. The

248 boundary to the overlying Baysun Formation is sharp. The Baysun Formation is similar to

249 that in the Kugitang Mountains, i.e. dominated by silty marl and marl with some

250 intercalations of oncoidal floatstones and micritic rudstones. The transition to the Kugitang

251 Formation is gradual (Fig. 5h). The Iron Gate section and the close-by Dalut Mine section

252 together represent a complete section through the investigated succession with a thickness of

253 approximately $935 \mathrm{~m}$ (Figs. 8, 10).

254

255 (6)-(7) Shargun sections (358 m; Fig. 11). - The coal mine north of the town Shargun lies 115

$256 \mathrm{~km} \mathrm{NE}$ of Panjab. The metamorphic basement rocks are overlain by a thin conglomeratic

257 gravelstone followed by lenticular coarse-grained sandstone with tree trunks, wood remains,

258 abundant plant fragments, rootlet horizons, and a 2-m-thick coal bed.From $40 \mathrm{~m}$ to $290 \mathrm{~m}$ the

259 succession is dominated by stacked, several-m-thick sandstone packages with erosional base,

260 large-scale trough cross-bedding, and abundant wood pieces and wood logs (Fig. 5c).

261 Towards the top these sandstone packages become thinner and fine-grained, and occasional

262 carbonaceous intercalations increase in thickness. The marine part of the succession is merely

$26364 \mathrm{~m}$ thick and consists of $14 \mathrm{~m}$ predominantly siliciclastic sediments 
264 (Degibadam/Tangiduval Formation) followed by $50 \mathrm{~m}$ of fine-grained, mixed carbonate-

265 siliciclastic sediments of the Baysun Formation. Unfortunately, no ammonites were

266 recovered. Quite possibly, the boundaries of the formations are diachronous when compared

267 with the sections in the Kugitang Mountains.

(8) Sangardak section (328 m; Fig. 12). - The section has a similar thickness as the close-by

270 Shargun section, but coarse-grained sandstones are mainly restricted to the lower $60 \mathrm{~m}$ of the

271 section, the remaining non-marine part of the succession being dominated by argillaceous silt.

272 The marine part is twice as thick $(131 \mathrm{~m})$ as at Shargun $(64 \mathrm{~m})$, and the Baysun Formation is

273 missing. The sandstones in the mixed carbonate-siliciclastic Tangiduval Formation are

274 coarser than in the other sections. The base of the overlying Kugitang Formation contains, in

275 contrast to most other sections, planar cross-bedded oo-grainstones.

276

277 (9)-(10) Vuariz sections (84 m; Figs. 13, 14). - Four short sections, 1.5 to $2.5 \mathrm{~km}$ apart, were 278 measured north and northeast of the Vuariz village. The distance to the Dalut Mine section is $27961 \mathrm{~km}$. The first two sections, which strongly overlap, comprise the Gurud Formation (82 m) 280 up to the base of the Degibadam Formation (Fig. 13a, b). The Palaeozoic basement is overlain 281 by a thin conglomerate and a few metres of poorly exposed carbonaceous argillaceous silt 282 followed by a 48-m-thick stack of coarse-grained, partly conglomeratic sandstones, with 283 erosional bases. Towards the top fine-grained siliciclastics with plant debris and root 284 horizons, which are subordinate in the lower half, dominate. Remarkable is the strongly 285 reduced thickness of the Gurud Formation.

286 The transgression is indicated by trace fossils and shell concentrations. The

287 Degibadam and Tangiduval formations cannot be differentiated and comprise only around 25 $288 \mathrm{~m}$ of sandstones, bioclastic sandy siltstones and soft silt (Fig. 13c). The Baysun Formation 289 starts with nearly $40 \mathrm{~m}$ of bioturbated limestones, mainly onco-floatstones, -rudstones, and 290 fine-grained intra-packstones topped by nearly $5 \mathrm{~m}$ of oo-grainstones. The following 291 approximately $50 \mathrm{~m}$ to the base of the Kugitang Formation have been removed by faulting. A 292 26-m-thick lateral equivalent of the carbonates, largely developed as peritidal packstones with 293 birdseyes and fenestral fabrics, has been measured beyond the northeastern end of the pass at

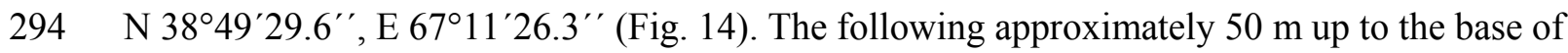
295 the Kugitang Formation are largely covered by scree, but are clearly composed predominantly 296 of soft, fine-grained sediments (?marl/silty marl). The base of the Kugitang Formation 
consists of $6 \mathrm{~m}$ of coarse-grained, partly gravelly, large-scale trough cross-bedded sandstones alternating with sandy lime mudstone beds.

Facies associations and palaeoenvironments

302

The investigated succession consists of continental facies in the lower part and of fully marine environments in the upper part. The transgressive surface is difficult to pinpoint sedimentologically but can be identified with the help of trace fossils. The following chapter is a brief description and discussion of the main environments. A summary can be found in Table 2.

Braided river deposits (e.g., basal parts of Vuariz, Shalkan, and Vandob sections; lower part

313 Coarse-grained to gravely or conglomeratic sandstone bodies that fine up to medium or fine

314 grain size are composed of stacked units with convex erosional bases and lateral variations in 315 thickness. They form packages up to $35 \mathrm{~m}$ in thickness and occur mainly at the base of the 316 Jurassic succession. The degree of maturity strongly varies: In some areas (e.g., at Vandob)

317 sand grains and pebbles consist mainly of quartz and mica flakes are common, in others the 318 sandstones are arkosic or lithic and the pebbles consist of black chert, metamorphic rock 319 fragments and subangular to subrounded quartz (e.g., at Shalkan, and Vuariz; Fig. 16a). Wood

320 fragments are abundant and locally tree trunks may be found at the base of the individual 321 units. Large-scale trough cross-stratification is pervasive. It may grade into ripple lamination 322 in the finer-grained top parts.

The sandstones can be interpreted as the fills of amalgamated shallow braided river

324 channels. The commonly immature nature of the sediments points to a close-by source area.

325 The stacking pattern of the channels (e.g., at Vandob and Shargun; Fig. 5g) reflects

326 equilibrium conditions between subsidence and deposition. 
332 In the Gurud Formation, fine- to coarse-grained, commonly arkosic sandstones with erosional

333 base, several metres to decametres in thickness, exhibit large-scale trough cross-stratification.

334 They fine up into ripple-laminated silty sandstone or siltstone, and in some cases the top is

335 rooted. Plant debris and wood fragments are common, and wood logs occur occasionally near

336 the base of the sandstone bodies. Distinct epsilon cross-bedding is developed in some cases

337 (e.g., in the Dalut Mine section; Fig. 9b). Stacking of several-metres-thick sandstone bodies is

338 commonly seen. In the valley immediately $\mathrm{W}$ of the Shargun section intercalated dark-grey

339 silty clay with some indistinct siltstone beds may laterally grade into intercalations of thick

340 siltstone-sandstone beds with epsilon cross-bedding.

341 The sandstone bodies clearly are the fill of fluvial channels (Miall 1996). Epsilon

342 cross-bedded units can be interpreted as point-bar deposits produced by lateral migration of

343 the channel. The fine-grained, thinner-bedded top parts of individual units with occasional

344 rootlets correspond to levee deposits. These fluvial channels are clearly of the meandering

345 type. The lenticular fine-grained deposits that laterally grade into point-bar deposits are

346 interpreted as the fills of abandoned channels (oxbow lakes).

Flood plain deposits (e.g., Dalut Mine section at 70-82 and 86-97 m; Fig. 15c)

350

351 Dark-grey argillaceous silt and silty clay with intercalations of $\mathrm{cm}$ - to dm-thick siltstones and

352 fine-grained sandstones with sharp, commonly erosional base, rich in plant debris, are

353 widespread in the Gurud Formation. The sandstones exhibit large-scale trough cross-bedding

354 or current ripple-lamination and occasionally are topped by a rootlet horizon. The fine-grained

355 sediments in-between are, in some cases, highly carbonaceous and may contain thin layers of

356 coal. Rarely, strongly ferruginous, mottled, fine-sandy silt layers with rootlets form

357 conspicuous horizons. At the base of the Shalkan section (Fig. 3) brown clay with scattered

358 quartz granules fills pockets of the underlying deeply weathered metamorphic Palaeozoic

359 basement.

360 The argillaceous silt is an alluvial deposit. The sandstone/siltstone interbeds

361 correspond to overbank deposits (crevasse splays) that formed on a swampy flood plain with

362 vegetation (rootlets) that was occasionally so dense that highly carbonaceous to coaly rocks

363 resulted. Mottled ferruginous siltstones are interpreted as soil horizons on a wet flood plain. A

364 different kind of paleosol occurs at the base of the Shalkan section. The very poorly sorted 
365 brown gravely clay is a brown soil, rich in iron, that today forms in temperate climates (e.g.,

366 Schaetzl \& Anderson 2005). Together with the strongly altered basement it points to a

367 prolonged phase of weathering on the incipient flood plain.

368

369

370

Swamps (e.g., Dalut Mine section at 40-47 m, 267 m, 418 m, 500 m; Shargun section at 17-19

371

372 Coal layers and dark-grey to blackish, highly carbonaceous clay or silty clay, rich in plant

373 fragments and underlain by rootlet horizons, are interpreted as swamp deposits. Commonly,

374 such swamps formed at the margins of lakes as can be seen from their stratigraphic context

375 (e.g., in the Dalut Mine section at $267 \mathrm{~m}$ ), but also developed on wet flood plains (e.g., Dalut

376 Mine section at $500 \mathrm{~m}$ ). The thickest coal layer recorded in any of the sections was $120 \mathrm{~cm}$

377 thick.

378 In many of the coal layers and highly carbonaceous fine-grained siliciclastics of the

379 Gurud Formation the plant material is, however, allochthonous. This assumption is

380 corroborated by their occurrence within lake successions (e.g., Dalut Mine section at 318-322

$381 \mathrm{~m}$ ) and by a lack of rootlet horizons. Apparently, the plant material has been transported into

382 the lakes from swampy coastal areas or has been introduced by rivers that reworked swamp

383 deposits on the flood plain.

384

385 Lake deposits (e.g., Dalut Mine section at 24-40 m, 234-267 m, 396-429 m, Shalkan section

386 395-453 m, Fig. 15e, f)

387

388 Monotonous dark-grey argillaceous silt and silty clay, in some horizons strongly

389 carbonaceous or with dm-thick coal layers, are the dominant facies types in the Gurud

390 Formation of the Shalkan and Dalut Mine sections. The fine-grained siliciclastics are

391 occasionally interrupted by $\mathrm{cm}$ - to dm-thick fine-grained sandstones that exhibit ripple

392 lamination and may contain wood fragments. Large orange carbonate and claystone

393 concretions occur at some levels; small ferruginous concretions are rare. A second very

394 common facies association in these two sections are m-scale coarsening-upward cycles. They

395 start with dark-grey argillaceous silt or silty clay and grade upward into silt, fine-sandy silt

396 and fine-grained sandstone. Plant fragments, carbonaceous beds and thin coal layers are

397 common. Rarely, finely interlayered bedding is developed at the base of such cycles. The

398 silty-sandy beds commonly are ripple-laminated and the top sandstones often exhibit large- 
scale trough cross-stratification and occasionally rootlets. In some cases (e.g. Shalkan section

400

401

402

403

404

405

406

407

408

409

410

411

412

413

414

415

416

417

418

419

420

421

422

423

424

425

426

427

428

429

430

431

432 at $356 \mathrm{~m}$ ) bedded fine-grained sandstones are parallel-laminated with sharp erosional base or display hummocky cross-stratification. Some of the large-scale cross-bedded sandstones on top of the cycles display a sharp erosional base.

The facies associations described above are best interpreted as deposits of various lake subenvironments. The monotonous fine-grained siliciclastic sediments clearly correspond to basinal parts of lakes. Thin coal layers, common plant debris, and the carbonaceous nature of some beds indicate that much plant material was introduced into the lakes which must have been surrounded by dense vegetation. The coarsening-upward sequences are progradational cycles that record shallowing of the lake from basinal to marginal environments. They also document an increase in water energy as is shown by the primary sedimentary structures. Rootlet horizons at the top of the some of the cycles indicate a transition to swampy areas. Rare HCS and parallel-laminated beds are evidence that parts of the lakes were influenced by storm-waves and storm-induced flows. These coarsening-upward successions document the development from offshore to shoreface and foreshore environments and are probably related to lacustrine delta progradation. A distinction between the two developments is difficult, if no fluvial channel is found on top of the shallowing sequence.

The size, depth, and duration of these lakes differed considerably, judging from the variable thicknesses of the lacustrine sediments. Small shallow lakes and large lakes, persisting for thousands of years, apparently existed side by side. Moreover, the common development of progradational cycles (see below) points to repeated phases of contraction and expansion of these lakes.

Following the transgression in the Late Bajocian, several marine facies associations are documented in the Degibadam, Tangiduval, and Baysun formations.

Distributary channel deposits (e.g., Iron Gate section at 97-115 m, Vandob section at 378388 m, Shalkan section at 617-634 m; Fig. 15g)

Ten- to twenty-metres-thick packages of immature sandstone with a sharp erosional base, fining up-section from medium or coarse to a fine grain size are found in the marine Degibadam Formation of the Iron Gate (Fig. 9d top), Vandob, and Shalkan sections. Sedimentary structures change up-section from large-scale trough cross-bedding to ripplelamination. Wood pieces are common, particularly near the base. 
Their erosional base and fining-upward nature identify the sandstones as channel

434 deposits. At Vandob and Iron Gate they are underlain by coarsening-upward successions

435 interpreted as delta front deposits (see below). Consequently the channel deposits represent

436 distributary channels of the delta plain.

437

Prodelta and delta front deposits (e.g., Iron Gate section 55-97 m, Vandob section at 370-388 m; Fig. 15h, i)

In the case of the Iron Gate section, the coarse-grained sandstones interpreted as fill of a

442 distributary channel are underlain by six metre-scale coarsening-upward sequences grading

443 from fine-grained ripple-laminated sandstone to medium-grained large-scale trough cross-

444 bedded sandstone (Fig. 16g). In one sequence, HCS was encountered in the basal part, in

445 another sharp-based parallel-laminated sandstone beds occur in the same position. Wood

446 pieces are present in two of the cycles. Trace fossils include Thalassinoides and Gyrochorte.

447 Below these units bioturbated silty clay prevails. It contains $\mathrm{cm}$ - to dm-thick

448 intercalations of ripple- or parallel-laminated sandstone, spaced 1 to $2 \mathrm{~m}$, with Gyrochorte,

449 some wood fragments, and rare ammonites.

450 The strongly bioturbated fine-grained units are interpreted as prodelta deposits which

451 are occasionally punctuated by coarser hyperpycnal flow deposits which may reflect flooding

452 events in the hinterland and a corresponding greater discharge of sediment-laden waters (e.g.,

453 Mutti et al. 2003). They grade upwards into stacked lower to upper delta-front cycles. The

454 increase in grain size and the change from ripple lamination to large-scale cross-bedding

455 indicates an increase in the energy level due to shallowing. In the Vandob section, the delta

456 front deposits are composed of amalgamated HCS sandstones which develop from

457 bioturbated silty fine-grained sandstone. At Shalkan, in contrast, the distributary sandstones

458 are underlain with sharp boundary by argillaceous silt, which documents a sudden lowering of

459 the base level.

460

461 Deposits of the tide-influenced inner siliciclastic ramp (e.g., Panjab section at 24-39 m;

462 Vandob section at 483-494 m; Fig. 15j)

463

464 In the Panjab section interlayered bedding is prevalent for about $15 \mathrm{~m}$ near the base of the

465 exposed succession. It is developed either as coarsely interlayered bedding consisting of 2- to

466 5-cm-thick ripple-laminated fine-grained sandstone beds and thin argillaceous interbeds or as 
467 a finer variety where sandstones are $0.5-1 \mathrm{~cm}$ and argillaceous silt interbeds $1-2 \mathrm{~cm}$ in

468 thickness. Near the top of this facies type a 50-cm-thick ripple-laminated, medium-grained

469 sandstone occurs. It has a sharp base, contains mud clasts, and displays some lenticular

470 bedding in the middle. Lenticular bedding and flaser bedding usually occur associated with

471 the interlayered bedding in the Panjab and Vandob sections.

472 The interlayered, flaser, and lenticular bedding points to regular changes in water

473 energy suggestive of some tidal influence (but not necessarily of intertidal conditions). The

474 medium-grained sandstone with clay pebbles may be the submarine continuation of a tidal

475 channel.

476

477 Protected low-energy inner ramp deposits (e.g., Shalkan section at 571-574 and 577-596 m,

478 Vandob section at 406-452 m; Panjab section at 34-36 m; Fig. 15k)

479

480 In the upper part of the Degibadam Formation of the Kugitang Mountains dark-grey, partly

481 bioturbated, argillaceous silt and fine-sandy silty clay predominate. At Vandob they are rich

482 in plant fragments. Highly carbonaceous levels are also present. Intercalated between these

483 fine-grained sediments are cm-thick fine-grained sandstone beds. In the Shalkan section they

484 are parallel laminated and form the top of metre-scale coarsening-upward sequences that start

485 with argillaceous silt, which grades into ripple-laminated siltstones as an intermediate facies.

486 The scarcity of large-scale sedimentary structures, the predominantly fine-grained

487 sediment, and the pervasive bioturbation point to prevalent low-energy conditions. The high

488 organic carbon content, including highly carbonaceous beds, suggests that the sediments were

489 deposited nearshore, most likely in a protected embayment. The coarsening-upward cycles

490 record shallowing and the intermittent influence of storm-induced flows.

491

492 Submarine dune deposits of the inner to middle siliciclastic ramp (e.g., Panjab section at 95-

$49398.0 \mathrm{~m}$, and 102.5-104 m, Vandob section at 542-545.5 m, Shalkan section at 646-648.5 m;

494 Fig. 15l)

495

496 Dm- to m-thick, commonly bioclastic, fine- to medium-grained sandstones with large-scale

497 cross-stratification and sharp base occur repeatedly in the Tangiduval Formation of the

498 Panjab, Shalkan, and Vandob sections. They are commonly associated with shell debris, more

499 rarely with pavements and lenticles of disarticulated bivalve shells, and form the upper part of

500 coarsening-upward sequences. The top of the sandstones exhibits, in some cases, oscillation 
501 ripples. Beds lower down in the succession may also be thoroughly bioturbated (e.g., Fig.

502 16c).

503 The sedimentary structures indicate deposition during high-energy conditions and, at

504 the top, occasional wave influence. Abundant bioclasts and mollusc remains point to fully

505 marine conditions. Found at the top of coarsening- and shallowing-upward cycles they are

506 interpreted as small submarine dunes that developed on the middle to partly inner siliciclastic

507 ramp. Alternatively, they may represent upper shoreface deposits.

508

509 Storm-wave dominated middle siliciclastic ramp deposits (e.g., Vandob section at 503-514 m,

510 Shalkan section at 454-513 m, 524-540 m; Fig. 15m)

512 In the Kugitang Mountains the lower part of the marine succession is characterised by

513 bioturbated argillaceous silt or silt with numerous intercalations of fine-grained cm- to dm-

514 thick sandstones. The latter have a sharp base and exhibit HCS (e.g. Fig. 16b), in some cases

515 ripple lamination. The thicker HCS beds are commonly amalgamated. Bedding planes

516 occasionally are developed as shell pavements, whereas in the bioturbated parts scattered

517 bivalves (e.g., Myopholas, Pseudolimea, Pleuromya), rare ammonites, some wood fragments,

518 and the trace fossils Chondrites and Taenidium occur. Generally, the HCS sandstones are

519 arranged as thickening-upward cycles.

520 The fossils indicate a fully marine environment. The finer-grained, high bioturbated

521 sediment document low-energy conditions, whereas the sandstones with HCS can be

522 interpreted as products of storm waves (e.g., Aigner 1979; Aigner \& Reineck 1982). The

523 depositional environment can therefore be classified as the middle ramp below the fair-

524 weather wave-base.

525

526 Storm-flow influenced outer siliciclastic ramp deposits (e.g., Iron Gate section at 14-39 m,

527 Panjab section at 4-16 m, Dalut Mine section at 552-562 m, Vandob section at 461-483 m;

528 Fig. 15n)

529

530 A facies association composed of highly bioturbated argillaceous silt alternating with cm-

531 thick fine-grained sandstones that exhibit ripple lamination or parallel lamination topped by

532 ripple lamination is common in the Bajocian marine succession of southern Uzbekistan. The

533 sandstones have a sharp base and are commonly associated with flute casts and/or tool marks.

534 Sand-filled structures, semicircular in cross-section and often with a shell lag at the base, 
occur isolated or at the base of the sandstone beds. Trace fossils include Gyrochorte,

536 Chondrites, Thalassinoides, and Rhizocorallium irregulare. Bivalves such as Meleagrinella

537 commonly form shell pavements, ammonites are rare.

538 As in the case of sandstones produced by storm-waves (see above), the parallel- and/or

539

540

541

542

543

544

545

546

547

548

549

550

551

552

553

554

555

556

557

558

559

560

561

562

563

564

565

566

567

568 ripple-laminated sandstones indicate brief high-energy events that episodically disturbed a generally low-energy environment. The sharp base with flute casts and the semi-circular sandstones are indicative of erosional events produced by a high flow regime, whereas normal grading and the change from parallel to ripple lamination within single beds is evidence of flow deceleration. The semi-circular sandstones are interpreted as gutter casts, i.e. narrow, elongated erosional structures (Aigner 1982). All these features are characteristic of the outer ramp under the episodic influence of storm-induced offshore-directed currents that originate after the waning of storms (e.g., Aigner \& Reineck 1982). The fine-grained bioturbated background sediment, in contrast, indicates low energy conditions.

Low-energy mixed carbonate-siliciclastic outer ramp deposits (e.g., Shalkan section at 732830 m, Vandob section at 580-696 m, Panjab section at 142-207 m; Fig. 15o)

The lower part of the Baysun Formation in all sections is characterized by monotonous finegrained, partly shaley, partly bioturbated silty marl. Poorly preserved small bivalves such as Corbulomima and Nicaniella occur scattered or concentrated in thin bands.

The sediments clearly belong to the low-energy outer ramp. The silt has been most likely introduced by suspension clouds, possibly in connection with storms, or by bed-load transport in form of thin laminae and streaks which subsequently were destroyed by bioturbation. The thin shell concentrations testify that occasionally winnowing took place, probably produced by distal storm-induced flows.

Condensed mixed carbonate-siliciclastic outer ramp deposits (e.g., Vandob section at 573579 m, Shalkan section at 729-733 m, Panjab section at 141-144 m; Fig. 15p)

At the base of the Baysun Formation, several metres of strongly bioturbated, rubbly, partly nodular, fine-sandy bio-wacke- to biofloatstone with interbeds of marly silt are developed in the Kugitang Mountains and at Panjab. The beds are highly fossiliferous with common bivalves (e.g., Entolium, Pleuromya, Ctenostreon, large Liostrea, and Bucardiomya), ammonites (mainly large Procerites), brachiopods, and some gastropods (e.g., Obornella). 
Many of the bivalves are articulated and some of the burrowing bivalves are preserved in

570 growth position.

571 Considering that ammonites are generally rare in the succession, the abundant

572 ammonites and in situ preserved benthic faunal elements point to low rates of sedimentation

573 persisting for quite some time. This increased the proportion of biogenic hardparts in the

574 sediment. The facies is clearly condensed compared to the sediments below and above, but

575 stratigraphic condensation i.e., mixing of taxa belonging to different zones or subzones, has

576 not been observed. Both sediment and taphonomic features indicate a low-energy outer ramp

577 environment.

578

579

Low-energy marl and mud- to wacke-/floatstones of the outer carbonate ramp (e.g., Vandob

580 section at 696-799 m, Iron Gate section at 280-409 m, Panjab section at 207-330 m; Fig.

$58115 q)$

582

583 This facies association is similar to the last one except that the silt fraction is negligible.

584 Bioturbation is pervasive and primary sedimentary structures are absent. The wacke- to

585 floatstones are bioclastic and commonly contain oncoids (Fig. 16e, f). Occasional packstone

586 beds consist mainly of bioclasts. The carbonates commonly have a nodular texture. Trace

587 fossils include Thalassinoides, and body fossils occasional bivalves (e.g., Pleuromya,

588 Protocardia, Corbulomima, oysters), rare gastropods (Pseudomelania), corals, and

589 ammonites (Macrocephalites).

$590 \quad$ Occasionally, bio-onco-rudstones are intercalated within the succession (e.g., Fig.

591 16d). As their matrix is, in most cases, micritic and as they exhibit a nodular texture it is

592 likely that they formed in-situ on the outer ramp. In contrast, rare, thin beds of rudstone with

593 sparitic matrix and small coated grains or oyster fragments most likely were introduced from

594 shallower areas of the ramp by storms.

595

596 Low-energy, peritidal lagoonal carbonates (Vuariz section IV; Fig. 14)

597

598 Sediments of peritidal origin are rare in the investigated succession. They have been

599 encountered only in the Baysun Formation of Vuariz. The sediments consist of very fine-

600 grained packstones, rarely of carbonate mudstones, with scattered birdseyes and laminoid

601 fenestral fabrics (Fig. 14). Repeatedly, cm-thick, irregularly laminated bands are intercalated 
602 as are rare beds of oncoid rudstones. Scattered gastropods are the only faunal element. The

603 birdseye limestones develop from onco-floatstones embedded in a fine packstone matrix.

604 Birdseyes, laminoid fenestral fabrics, and fine, irregular lamination are typical of algal

605 origin and generally interpreted as having formed in the intertidal to very shallow subtidal

606 zone (e.g., Shinn 1983; Flügel 2010). At Vuariz they are the lateral equivalent of ooid

607 grainstones (Vuariz section III; Fig. 13c). This suggests that they formed in a low-energy

608 lagoonal environment protected by ooid bars. Their occurrence in the Baysun Formation,

609 which at most other sections represents offshore environments, supports the interpretation of

610 the Vuariz area as being close to the basin margin.

611

612 Macroflora and benthic macrofauna

613

614 Several land plant associations have been recognised in the non-marine part of the succession,

615 but no identifiable macroflora has been encountered during the field work. Thus, Gomolitzky

616 (in Shayakubov \& Dalimov 1998) recognised the Kamyshbash Flora (with e.g., Osmundopsis

617 Phlebopteris, Dictyophyllum, Thaumatopteris, and Nilssonia) and the Shurab Flora (documented

618 by Neocalamites, Marattiopsis, Coniopteris, Phlebopteris, Clathropteris, Dictyophyllum,

619 Hausmannia, Cladophlebis, and Anomozamites gracilis) in the Lower Jurassic Sandzhar

620 Formation and another association with Equisetum, Mazattina, Coniopteris, Cladophlebis,

621 Ptilophyllum, and Nilssonia in the Gurud Formation. According to Vakhrameev et al. (1988)

622 floral associations allow to differentiate between the Hettangian-Sinemurian, Toarcian, Aalenian,

623 Bajocian, and Bathonian stages. These associations have been used extensively to date the non-

624 marine rocks.

625 No benthic macrofauna has been found in the non-marine part, in which Martinson and

626 Mikulina (in Shayakubov \& Dalimov 1998) recorded molluscan assemblages characterized by the

627 bivalves Unio, Ferganoconcha, and Sibireconcha (Kim et al. 2007). In the marine part of the

628 succession bivalves are common at some levels. In the Upper Bajocian they commonly form

629 pavements of disarticulated valves, common elements being the infaunal Myopholas and the

630 epibyssate Camptonectes. Bivalves increase in abundance in the Tangiduval Formation and

631 particularly in the condensed basal beds of the Baysun Formation. Common taxa include

632 Pholadomya (Bucardiomya), Pleuromya, Homomya, Inoperna, Integricardium, Protocardia,

633 Actinostreon, Liostrea, and Nanogyra. These genera are typical elements of the benthic

634 macrofauna occurring in shallow-marine environments of the Jurassic epicontinental seas from

635 western and eastern Europe to Iran. Gastropods (e.g., Obornella) are comparatively rare as are 
brachiopods, the latter occurring mainly in the condensed base of the Baysun Formation where they are represented by at least five genera.

At a first glance, the marls and silty marls of the Baysun Formation appear to be devoid of fossils, but in fresh material small infaunal bivalves such as Corbulomima and Nicaniella are common at numerous levels as poorly preserved composite or external moulds. They constitute typical softground assemblages, well known from numerous fine-grained Jurassic successions

642 elsewhere (e.g., Fürsich 1977; Fürsich \& Werner 1986; Fürsich et al. 2004). As the percentage of

643 endemic faunal elements appears to be low, the Amu Darya and Afghan-Tajik basins appear to

644 have been well connected with other shelf seas situated on the southern margin of the Turan

645 Platform.

646

647

\section{Cycles}

649

650

As has been mentioned in the facies descriptions, the various facies are commonly organised into cycles. These cycles are highly asymmetric and represent either thickening-/coarsening-

652 upward cycles or fining-/thinning-upwards sequences.

653

654

Fluvial cycles (Fig. 17a, b)

655

656 Fining-upward cycles are nearly exclusively developed in the non-marine part of the

657 succession. They start with fine-to coarse-grained, large-scale trough cross-stratified

658 sandstones, which may be gravelly or pebbly, and exhibit an erosional base. Up-section they

659 fine to ripple-laminated sandstone or siltstone and, finally, to argillaceous silt.

660 These cycles can be interpreted as classical fluvial cycles, the basal sandstone

661 representing channel deposits which fine upwards into levee deposits, which may be rooted,

662 and into fine-grained sediments of the flood plain. Commonly these cycles are stacked on top

663 of each other and the fine-grained parts often have been cannibalized by the next channel

664 generation (e.g., in the Shargun section at 0-32 $\mathrm{m}$ and the Vandob section at 0-12 m). This

665 applies particularly to braided river channels as at Vandob, but is also seen in the point-bar

666 deposits composing the lower $32 \mathrm{~m}$ of the Shargun section. In the latter case, the flood plain

667 must have been relatively narrow so that laterally migrating channels repeatedly cut into older 668 channel deposits.

669

670

Progradational lacustrine cycles (Fig. 17 c, d) 
672 Coarsening- and thickening-upward cycles are widespread in the lacustrine successions of the

673 Gurud Formation. Starting with argillaceous silt to silty clay, these sediments are followed by 674 intercalations of thin ripple-laminated siltstone to fine-grained sandstone beds which thicken 675 upwards into m-thick fine-grained sandstone, the top of which may be rooted and followed by 676 coal. In some cases, the latter is overlain by large-scale trough cross-bedded fine- to medium677 grained sandstones with erosional base.

678 These cycles indicate a shallowing of the lake, commonly caused by progradation of 679 small deltas. This is confirmed where the top sandstone is a lenticular deposit, which can be 680 interpreted as a distributary channel. In other cases, the shallowing was a result of lacustrine 681 coastline progradation and led to the development of swamps as is demonstrated by root 682 horizons and/or coal layers. The fact that these lacustrine progradational cycles are often only 683 a few metres thick and alternate with fluvial channel and flood plain deposits indicates that 684 most of the lakes were shallow and of limited extent and duration.

685

686

Marine deltaic cycles (Fig. 17e)

687

688

Large-scale, decametre-thick thickening- and coarsening-upward cycles are comparatively

689 rare and restricted to the Degibadam Formation (e.g., in the Iron Gate and Vandob sections). They start with bioturbated silty clay to fine-sandy silt, followed by ripple-laminated, parallellaminated or hummocky to large-scale trough cross-stratified sandstones. The latter are cut by distinctly incised large-scale trough cross-bedded medium- to coarse-grained sandstones, which in the case of the Vandob example contain large wood fragments. In the case of the

694 Iron Gate section, this nearly 20-m-thick sandstone body fines upwards into ripple-laminated 695 fine-grained sandstones (Fig. 20).

696 The described successions are classical delta cycles (e.g., Reading \& Collinson 1996), 697 starting with bioturbated prodelta deposits which are replaced up-section by delta-front 698 sandstones, partly under storm-wave influence and end with large distributary channels. In the 699 Iron Gate section (Fig. 10 at 70-96 m) several delta-front sandstone cycles are stacked on top 700 of each other recording either autocyclic switching of the position of the nearby distributary 701 channel or small-scale sea-level fluctuations.

702 
Much of the Degibadam Formation is composed of cycles which are usually a few metres in thickness and start with strongly bioturbated silty clay to silt with sporadic intercalations of cm-thick HCS sandstones. These sandstones thicken up-section and become more common. The top bed often is a dm- to m-thick fine-grained sandstone composed of amalgamated HCS beds. Modifications of this cycle type consist of bioturbated silt coarsening-upward into finegrained sandstone with only the top bed exhibiting HCS (e.g., Vandob section at 296-302 m and 337-370 m).

The widespread hummocky cross-stratification indicates that these cycles developed on the storm-wave influenced middle ramp. The increase in grain size, bed thickness, and abundance of HCS beds up-section either record shallowing and a shift of the depositional environment towards the inner part of the middle ramp or else increasing storm intensity, in this case being a climatic signal and not necessarily involving changes in relative sea level (resulting from local vertical movements due to tectonics and from eustasy). However, even changes in relative sea level may be ultimately climatically controlled in shallow-water areas by greater erosion and run-off during more humid phases.

Cycles where only the top part exhibits HCS, the rest being thoroughly bioturbated, probably represent the outer middle ramp close to the storm wave-base, where much evidence of storm-wave sedimentation was subsequently destroyed by bioturbation.

\section{Cycles of the outer to middle siliciclastic ramp (Fig. 17g)}

Metre-scale cycles composed of bioturbated argillaceous silt which grades into bioturbated to ripple-laminated fine-grained sandstone and end with large-scale trough cross-bedded sandstone occur commonly in the Tangiduval Formation. Bivalves and brachiopods may occur in the bioturbated parts, while in the cross-bedded top part shell debris prevails.

The cycles reflect an increase in the energy level, most likely in connection with shallowing. The cross-bedded top unit is interpreted as megaripples or small dunes, which may have migrated across the ramp during times of elevated water energy such as storms.

\section{Cycles of the storm-flow dominated outer siliciclastic ramp (Fig. 17h)}

Cycles of the siliciclastic outer ramp consist mainly of bioturbated argillaceous silt with occasional intercalations of 2-5 cm thick sharp-based ripple-laminated fine-grained sandstones. Towards the top, the density of the sandstone intercalations increases and the top 
sandstone bed may reach $10 \mathrm{~cm}$ or more in thickness. Occasionally the sandstones represent couplets whereby a parallel-laminated lower part is overlain by a ripple-laminated upper part. The lower surface of the sandstones exhibits flute casts and tool marks. In some cases, gutter casts are associated with the sandstones.

The sedimentary structures and lower surface features are indicative of short-lived high velocity currents produced by storm processes, which transport sand in an offshore direction (e.g., Walker \& Plint 1992). The increase in thickness and density of the sandstone beds reflects increasing storm intensity which most likely is related to shallowing but as discussed above might also be due to climatic changes. As HCS is not encountered, an outer ramp position of the cycles is envisaged.

\section{Cycles of the outer carbonate ramp (Fig. 17i,j)}

Cycles are also developed in the fine-grained mixed carbonate-siliciclastic part of the succession (Baysun Formation). They are several decimetres to metres in thickness and start with marl or silty marl, commonly shaley but also containing some winnowed pavements of small infaunal bivalves. Towards the top of the cycles the carbonate content increases, which is documented by bioturbated carbonate mudstones to bio-wackestones and onco-floatstones, commonly of a nodular texture.

These cycles are characterized by directed changes in the carbonate-clay ratio. They are interpreted as reflecting a decrease in the input of fine-grained siliciclastic material. This may have been brought about by an increasing distance of the sediment source and thus would correspond to a deepening, assuming that carbonate production remained more or less constant. The cycles can, however, be also explained to reflect shallowing, assuming that this led to increased carbonate production. The latter view is favoured due to the widespread occurrence of microbial oncoids, which are never present in the marls and which are evidence that the depositional environment was at least in the lower part of the photic zone. As in the case of some other cycles discussed above, an alternative explanation involving a reduced terrigenous input due to climatic changes is also feasible. The latter alternative would not require changes in water depth.

\section{Discussion}


775 The study area comprises only the northwestern part of the Afghan-Tadjik Basin. In this area,

776 the greatest thickness of the Lower Jurassic - Lower Callovian succession is found in the

777 Kugitang Mountains with 924 m (Shalkan section), the smallest at Sangardak (328 m),

778 although at Vuariz, where only part of the marine succession could be measured (the rest

779 could just be estimated), it is even considerably less (probably around 200-210 m).

780 Palaeogeographic facies maps have been produced by Egamberdiev and Ishniyazov (1990).

781 Their facies interpretations are, however, not always supported by our data.

782

783 Gurud Formation. The non-marine part of the succession reaches $453 \mathrm{~m}$ at Shalkan as 784 opposed to $290 \mathrm{~m}$ at Vandob, situated only $18 \mathrm{~km}$ further SSE. At the Dalut Mine near

785 Baysun (Fig. 1) the thickness of the formation is $534 \mathrm{~m}$, although this figure may not be quite correct as the section is disturbed by folding and faulting at two levels. Towards the border with Tajikistan at Shargun Mine the thickness of the formation is $290 \mathrm{~m}$ and at Vuariz a mere $88 \mathrm{~m}$. These figures suggest that the Palaeozoic basement exhibited a considerable relief and that the age of the lowest Jurassic sediments may differ considerably between the various areas. The facies pattern in the Kugitang Mountains and at the Dalut Mine is very similar: Alternations of fluvial sandstones, fine-grained flood plain deposits, thin coal seams indicative of swamps, and argillaceous-silty, often organic-rich, to sandy lacustrine deposits. Many of these lakes appear to have been small and to have become infilled rapidly, but the thick, uniform silty clay succession at Shalkan and probably also at Vandob must represent a large and deep lake persisting for a considerable period of time. At Shargun and Vuariz, in contrast, the Gurud Formation is strongly dominated by coarse-grained to gravelly fluvial channel deposits with fine-grained floodplain deposits being of only minor importance. Where the latter occur, they also contain coal beds, but lake deposits are rare.

The thickness and facies variations indicate that the area of the northern part of the

800 SW Gissar Mountains was a high area during the Early and early Middle Jurassic where 801 erosion took place at the time when further south, in the Kugitang Mountains, the Palaeozoic relief became already filled with sediment. At Vuariz and Shargun a short distance to the source area is also indicated by the coarse, highly immature sediment. The presence of

804 meandering river deposits at Shargun as opposed to braided stream deposits at Vuariz and the 805 very small thickness of the formation at the latter locality suggest that the Vuariz area was 806 very close to the sediment source. 
808 Degibadam and Tangiduval formations. At the top of the Gurud Formation the morphological

809 relief appears to have largely been levelled as the change to marine conditions was more or

810 less synchronous across the study area, from the Kugitang Mountains to the Dalut Mine and

811 the Iron Gate where Late Bajocian ammonites were found very close to the transgressive

812 surface. At the remaining sections either no ammonites have been recorded (e.g., Vuariz,

813 Shargun) or the transgressive surface is not exposed (e.g., at Panjab).

814 The thickness of the two formations is fairly uniform (276-284 m) except at Sangardak

$815(143 \mathrm{~m})$ and Shargun $(14 \mathrm{~m})$ where it is greatly reduced. In most of the study area the

816 sedimentation pattern was mosaic, oscillating between partly tidal-influenced, partly high-

817 energy inner ramp deposits, storm-wave influenced middle ramp deposits, and storm-flow

818 dominated outer ramp deposits. The common arrangement of the sediments in coarsening-

819 upward parasequences indicates that this sedimentation pattern was governed by changes in

820 relative sea level and probably also by cyclic changes in climate. From the Kugitang

821 Mountains to the Iron Gate the carbonate content of the sediment increases towards the top as

822 does the amount of molluscs, mainly bivalves.

823

824 Baysun Formation. The thickness of the Baysun Formation from Vandob to Panjab is similar

825 (195-226 m), but at Iron Gate it is reduced to $130 \mathrm{~m}$ and at Shargun to $51 \mathrm{~m}$,. The fairly

826 uniform sediment (marl or silty marl with intercalations of carbonate mud- and wackestones,

827 the latter increasing towards the top) continues the trend of strong reduction of even fine-

828 grained terrigenous input towards the top. In parts of the formation cycles recording an

829 increase in carbonate are developed which most likely reflect shallowing. At present it is not

830 clear how the strongly reduced Baysun Formation at Shargun should be explained. Due to the

831 lack of age-diagnostic fossils no statement can be made whether the boundaries of the

832 formation are isochronous or diachronous when compared with the remaining sections.

833 Moreover at close-by Sangardak, a fine-grained mixed carbonate-siliciclastic succession

834 resembling the Baysun Formation below the massive walls of the Kugitang Formation is

835 repeatedly interrupted by intercalations of medium- to coarse-grained ripple-laminated to

836 large-scale trough cross-bedded quartz sandstones. The latter feature points to a close-by

837 source area and a steep bathymetric gradient, underpinning that we are adjacent to a land area.

838 This view is corroborated by the fact that also in the basal part of the overlying Kugitang

839 Formation sandy intercalations are common and the carbonate microfacies (including oo-

840 grainstones) and sedimentary structures are indicative of a high energy setting (pers. comm. 
R. Bourillot, Dec. 2013). Similar features can be seen at Vuariz. Oo-grainstone intercalations

842 between marl and wackestones in the Baysun Formation at Vuariz and Shargun point to partly

843 shallow-water environments. At Vuariz, oo-grainstones and packstones, interpreted as high-

844 energy bars, are laterally replaced by algal limestones with birdseyes and fenestral fabrics

845 (Fig. 14), which are interpreted as representing lagoonal deposits of peritidal origin. Despite

846 these local differences in facies all localities show a gradual transition to the overlying thick-

847 bedded limestones of the Kugitang Formation. In the Kugitang Mountains this transition is

848 characterised by the complete lack of terrigenous input into the basin.

849

850

Palaeoenvironmental evolution of the northwestern Afghan-Tajik Basin: Interplay of

852 tectonics, eustatic sea-level changes, and climate (Fig. 19)

853

854 The evolution of the northwestern Afghan-Tajik Basin during the Jurassic has been shaped

855 mainly by tectonics, subsidence, eustatic sea-level changes, and climate. Extensional tectonics

856 (?back-arc rifting; Brookfield \& Hashmat 2001) starting in the Late Permian Triassic was

857 responsible for the formation of the basin (Ulmishek 2004; Klett et al. 2006), which was

858 apparently subdivided into a number of grabens and horsts. No Triassic sedimentary rocks

859 have been encountered in the study area (see also Dzhalilov et al. 1982) and sedimentation

860 appears to have started only in the Toarcian on the northern margin of the basin. The

861 basement consists mainly of Palaeozoic metamorphic rocks. Judging from the distinct

862 differences in thickness of the non-marine succession between some of the sections a

863 considerable relief must have existed during the Early Jurassic; consequently, the base of the

864 succession most likely is highly diachronous, although this cannot be proven by index fossils.

865

866 Non-marine stage. During the Late Early Jurassic erosion of elevated areas produced plenty

867 of sediment, and low-lying areas were filled with deposits of braided or meandering river. The

868 coarse-grained, highly immature sediment points to short transport distances. The stacking of

869 fluvial channels, a common feature in the lower part of the non-marine succession, can be

870 explained by relatively narrow river plains. In the Kugitang and Baysun areas levelling of the

871 relief must have occurred comparatively soon, as the mean grain size decreased distinctly

872 after a few tens of metres as did the sandstone-shale ratio. Up to the Early Bajocian extensive

873 flood plains existed which were dotted with lakes. Some of these lakes were apparently of

874 considerable size and duration, others only short-lived. The flood plains were also crossed by 
numerous streams, which commonly emptied into lakes where they built small deltas.

876 Swampy areas developed on the flood plain and especially at the margins of the lakes. The

877 dark-grained, organic-rich lake sediments, common root horizons, carbonaceous silt and coal

878 layers, and the ubiquitous plant and wood remains point to the presence of a dense vegetation

879 and consequently to a fairly humid climate. Subsidence and rate of sediment accumulation

880 appear to have been close to equilibrium. The cyclic nature of many lake deposits is the result

881 of lacustrine delta or shoreline progradation.

882 The comparatively thin non-marine successions at Shargun, Sangardak and especially

883 at Vuariz with their high sandstone-shale ratio suggest that sedimentation in these areas

884 started much later and that the sediment source was very close. Most likely, the central parts

885 of the Gissar Mountains were the main source area for the sediments delivered to the Baysun

886 and Kugitang mountains.

887

888 Marine stage. The sea invaded the area in the Late Bajocian. Evidence are the presence of

889 marine shells and trace fossils and finds of the ammonite Parkinsonia close to the lowermost

890 marine beds. As nowhere a transgressive conglomerate is developed and the transgressive

891 surface is very inconspicuous, a flat coastal plain must have existed at the time of

892 transgression. Wherever ammonite evidence is available, it suggests that flooding of the basin

893 took place at roughly the same time. A distinct transgression at this point in time is also

894 recorded from neighbouring basins such as the Kashafrud Basin in the Kopet Dagh area and

895 the southern margin of the South Caspian Basin (i.e., the Alborz Mountains) (Fürsich et al.

896 2009a). As the global sea-level started to rise in the late Early Bajocian (Hallam 2001), it is

897 tempting to relate the transgression to this eustatic signal. However, the two events are not

898 strictly synchronous. Moreover, the transgression in the Alborz area and in the Kopet Dagh

899 has been explained by Fürsich et al. (2009b) by a distinct subsidence pulse caused by the

900 onset of seafloor spreading in the South Caspian Basin. Similarly, in the Afghan-Tajik Basin

901 increased subsidence is thought to be the main factor causing the change to marine conditions

902 in the basin as well as in the Amu Darya Basin (Brunet et al. 201X).

903 The marine sediments were initially purely siliciclastic and range from argillaceous

904 silt to fine-grained sandstone. Abundant HCS and parallel-/ripple-laminated sandstones and

905 gutter casts indicate that for long time depositional environments corresponded to the storm-

906 wave and storm-flow influenced ramp. Commonly the sediments are organised in thickening-

907 and coarsening-upward parasequences which indicate to shallowing and thus correspond to

908 small-scale relative sea-level fluctuations. These parasequences may either reflect a eustatic 
signal or else climatic conditions which oscillated between dryer and wetter periods. During

910 the latter, sediment influx into the basin was higher and the storm intensity greater. The

911 greater storm intensity might have contributed to disperse coarser-grained coastal sediments

912 across the ramp.

913 Within the Upper Bajocian Degibadam Formation a thick deltaic complex is

914 developed in several sections (Vandob, Shalkan, Iron Gate, to a lesser extent also at Panjab).

915 These deltaic sandstones are most likely not coeval but are part of a succession with an inner

916 ramp character (shown e.g., by tidal influence and allochthonous coal layers). Apparently, at

917 this time the sedimentation rate exceeded subsidence on the margins of the basin resulting in

918 progradation of the shoreline.

919 The increasing carbonate content in the Tangiduval Formation does not go hand in

920 hand with a decreasing grain size of the siliciclastic material. It therefore appears that the

921 mixed carbonate-siliciclastic sediment is above all the result of increased carbonate

922 production and only secondarily due to a reduction in terrigenous input. Both features point to

923 a gradual change in climate from humid to increasingly drier and warmer conditions. The

924 input of siliciclastic material, however, decreased distinctly from the Middle Bathonian

925 onwards. This led to the formation of a several-metres-thick condensed unit at the base of the

926 Baysun Formation. This is the only level within the investigated time slice where ammonites

927 are common, associated with abundant benthic elements such as bivalves, gastropods and

928 brachiopods. During the Late Bathonian the percentage of silt gradually decreased so that by

929 the Early Callovian only clay-sized terrigenous material reached the southern part of the study

930 area which occupied an outer ramp to basinal position. The occurrence of concentrations of

931 small infaunal bivalves suggests that the sea floor was intermittently winnowed by currents.

932 The presence of bio-floatstones and, more rarely, bio-rudstones in a cyclical manner points to

933 phases during which the input of terrigenous fines ceased completely. The shell debris that

934 abounds in some of these carbonates is clearly of shallow-water origin and is commonly

935 associated with oncoids. Thus the depositional environment was within the photic zone. As

936 has been argued above, climatic changes are the most plausible cause for these carbonate

937 cycles.

938 The Baysun Formation at Sangardak and Shargun differed not only in a reduced

939 thickness from the remaining localities but also by intercalations of medium- to coarse-

940 grained quartz sandstones in the silty marl. The sharp base, sedimentary structures such as

941 ripple lamination and large-scale cross-bedding, and associated trace fossils (Ophiomorpha)

942 at Sangardak indicate episodic influx from a very nearby source area and a considerable relief. 
943 As this influx is very sudden, the most likely explanation is a tectonic origin that led to uplift

944 of a close-by land area. At Vuariz, in turn, the basin was considerably shallower leading to the

945 establishment of high-energy ooid bars and peritidal carbonate flats. Intercalations of coarse-

946 grained sandstones at the base of Kugitang Formation are interpreted in a similar way as at

947 Sangardak.

948 By Middle Callovian times, the terrigenous influx had ceased completely. As result a

949 carbonate regime became established across the study area. In most areas, the thick-bedded

950 limestones of the Kugitang Formation record low to moderate energy conditions below the

951 fair-weather wave-base which persisted until the Kimmeridgian, as subsidence and rate of

952 sedimentation continued to be close to equilibrium.

953

954 Sequence stratigraphic aspects (Fig. 20)

955

956 Both the marine and non-marine part of the succession exhibit a pronounced cyclicity. In the

957 non-marine part, this cyclicity is documented mainly by progradational lacustrine cycles

958 which might be partly autocyclic, partly reflecting changes in base level. As there is, however,

959 at present only a very coarse biostratigraphic control of the succession and the fine-grained

960 lacustrine succession in the Kugitang Mountains is only partly exposed no attempt at a

961 sequence stratigraphic interpretation is made.

962 In the marine succession two 3rd-order sequences spanning the Late Bajocian to Early

963 Callovian time interval can be recognised. They are very well seen in the Iron Gate section

964 (Fig. 20), although the transgressive systems tract (TST) of the lower sequence is missing. It

965 is represented in the Shalkan and Vandob sections by storm-influenced ramp sediments. The

966 maximum flooding zone (MFZ) is represented by bioturbated argillaceous silt. The highstand

967 systems tract (HST) starts again with storm-influenced ramp deposits, which grade into

968 prodelta, delta-front, and delta-top sediments (Iron Gate), the latter characterised by being

969 fine-grained and often carbonaceous with minor coal beds or exhibiting tidal influence. The

970 TST of the second sequence more or less coincides with the base of the Tangiduval Formation

971 and typically consists of sandy sediments with a calcareous matrix and common shell debris

972 and oyster shells. The MFZ is a several-metres-thick condensed unit, rich in ammonites and

973 benthic macrofauna and forms the base of the Baysun Formation. The HST comprises the

974 sediments of the Kugitang Formation. In contrast to what would be expected the terrigenous

975 input decreases towards the top. This, however, does not reflect increasing distance from the

976 shoreline but is the result of the distinct change to a more arid climate (see below). The base 
977 of the next sequence corresponds to the onset of a large carbonate ramp system (Kugitang

978 Formation), which is studied in detail in a companion project (Bourillot pers. comm.;

979 Carmeille et al. 2014).

980 As has been shown above, the 3-rd order sequences are composed of numerous

981 parasequences. Most likely, higher-order sequences may also be discernable in some cases,

982 but a more detailed analysis is beyond the scope of this paper.

983

984 Tectonics, sea-level fluctuations, and climate as driving mechanisms of the sedimentation

\section{5 pattern}

986

987 The main factors for the formation of the Afghan-Tajik Basin were extensional tectonics and

988 resulting subsidence (Brookfield \& Hashmat 2001; Ulmishek 2004). Differential uplift due to

989 block faulting influenced the sedimentation pattern as it created basins and uplifted areas, the

990 former receiving the sediment eroded from the latter. This setting must have created a mosaic

991 sediment pattern with areas close to horsts receiving coarser sediment than areas further away.

992 Apart from Vuariz and Shargun-Sangardak the study area must have occupied a relatively

993 basinal position as basement rocks are nowhere overlain by alluvial fan deposits but either by

994 paleosol or braided river deposits. Moreover, soon after deposition of the initial sandstones

995 fine-grained lake and flood plain deposits became conspicuous elements indicating little

996 relief. Tectonic activity appears to have been restricted to the major fault systems and

997 affecting sedimentation within the basin mainly by changes in the supply of coarser

998 siliciclastic material. A tectonic influence, documented by an angular unconformity,

999 apparently affected the area of Sangardak-Shargun somewhen in the Callovian (Fig. 9h). This

1000 unconformity is developed between the Baysun and the Kugitang Formation and can be

1001 explained by slight tilting of a fault block. How much sediment has been eroded prior to

1002 deposition of the carbonates of the Kugitang Formation cannot be reconstructed due to the

1003 insufficient stratigraphic control. Differential tectonic uplift is also documented by the

1004 thickness differences of the marine part of the succession which changed from $>400 \mathrm{~m}$ at the

1005 Iron Gate to $130 \mathrm{~m}$ at Sangardak and to $65 \mathrm{~m}$ at Shargun along a distance of $90 \mathrm{~km}$.

1006 Several factors appear to have shaped the overall basin development. According to

1007 Hardenbol et al. (1998) the peak of a transgressive-regressive megacycle occurred in the Late

1008 Bajocian. This major sea-level rise probably contributed to the flooding of the basin to some

1009 extent. In addition, the change to marine conditions could also have been caused by active

1010 subsidence or else by a general reduction of sediment input into the basin caused by an 
1011 increasingly lower relief of the hinterland and less humid conditions. A major change in

1012 climate towards drier and possibly warmer conditions is indicated by the change from

1013 siliciclastic to carbonate sedimentation from the Early to the late Middle Jurassic. This trend

1014 to increasing aridity continues into the Kimmeridgian and Tithonian when widespread

1015 evaporites and red beds dominated the sedimentation pattern.

1016 Controversial is the origin of the numerous parasequences that compose much of the

1017 rock succession. In the marine environments they correspond to relative changes in sea level

1018 which could be eustatic-, tectonic- or else climatic-controlled. As no clear pattern is visible

1019 that allows grouping these parasequences into higher hierarchy cycles a climatic control is

1020 thought to be more likely. In the non-marine part of the succession, in contrast, the fining-

1021 upward cycles developed on the flood plains and the progradational lacustrine cycles are

1022 thought to be largely the result of autocyclic processes but probably steered by an underlying

1023 climatic pattern that regulated the sediment supply.

1024 In conclusion, the Jurassic fill of the North Afghan-Tajik Basin reflects the interplay

1025 of extensional tectonics creating a syn-rift subsidence, a subsequent more regular thermal

1026 subsidence, eustatic sea-level changes, and climate, whereby the importance of the various

1027 factors varied through time.

1028

1029 Comparison with sedimentary basins in northern Iran

1031 In order to put the Jurassic history of the investigated northwestern part of the Afghan-Tajik

1032 Basin into a broader perspective, it is compared with the Jurassic history of neighbouring

1033 basins. For this reason, the geological development of two sedimentary basins in northern

1034 Iran, the Kashafrud Basin (Kopet Dagh) and the southern passive margin of the South

1035 Caspian Basin (Alborz Mountains), is briefly commented upon (Fig. 21).

1036 In the southern Alborz Mountains, marine conditions became established in some

1037 areas as early as the Hettangian (Fürsich et al. 2009a). In the Early Jurassic Alasht Formation

1038 and in the Early Bajocian Dansirit Formation terrestrial environments with lakes, fluvial

1039 systems and widespread coal swamps similar to those in the Afghan-Tajik Basin prevailed.

1040 In both basins a pronounced transgression took place in the Late Bajocian following

1041 the Mid Cimmerian tectonic event in the Early Bajocian (Fürsich et al. 2009a, b; Taheri et al.

1042 2009). In the case of the Alborz Mountains the origin of this transgression has been explained

1043 by these authors as related to the onset of sea-floor spreading in the South Caspian Basin. At

1044 the same time rifting, most likely related to Neotethys back-arc rifting, started in the Kopet 
1045 Dagh area and initiated the Kashafrud Basin, which has been interpreted as the eastward

1046 extension of the South Caspian Basin (Brunet et al. 2003, 2007; Taheri et al. 2009). In both

1047 basins siliciclastic sediments prevailed until they were gradually replaced by carbonates. This

1048 replacement started in the Kashafrud Basin in the Callovian with fine-grained mixed

1049 carbonate-siliciclastics of the Chaman Bid Formation and continued into the Late Jurassic

1050 with the establishment of a large carbonate platform system, the Mozduran Formation.

1051 On the southern passive margin of the South Caspian Basin, marine siliciclastic

1052 sediments overlying the Mid-Cimmerian unconformity are usually only a few metres thick,

1053 except in the eastern Alborz where the so-called Bashkalateh Formation (Afshar-Harb 1994),

1054 a lateral equivalent of the Kashafrud Formation of the Kopet Dagh (Seyed-Emami et al.

1055 2001), represents a largely fine-grained deep-marine environment with turbiditic

1056 intercalations. The change to a carbonate regime started already in Late Bajocian times, as is

1057 indicated by the silty marls and marls of the Dalichai Formation. Initially representing basinal

1058 sediments these marls change up-section to allodapic carbonates of the slope and finally to the

1059 shallow-water platform of the Callovian Tithonian Lar Formation. A similar change from

1060 fine-grained mixed carbonate-siliciclastic sediments to shallow-water carbonates occurs also

1061 in the Binalud Mountains of north-eastern Iran (pers. obs.). Moreover, the widespread

1062 replacement of siliciclastic sediments by carbonates towards the end of the Middle Jurassic

1063 can also be observed on the Tabas and Lut blocks of the Central-East Iranian microcontinent

1064 where the silty to marly Bathonian to Lower Callovian Baghamshah Formation grades up-

1065 section into the Upper Callovian to Oxfordian Esfandiar Limestone Formation (Wilmsen et

1066 al. 2009). As in the Afghan-Tajik Basin, the carbonates in the Iranian basins are generally

1067 followed by red beds and evaporites towards the end of the Jurassic.

1068 The replacement of siliciclastic sediments by carbonates is therefore a widespread

1069 feature and occurred not only in the Afghan-Tajik Basin as well as the Amu Darya Basin but

1070 also in various basins of Iran. This strongly suggests that the change in sedimentation pattern

1071 is due to a regional change towards more arid conditions.

1072 In the sedimentary basins east of the Afghan-Tajik Basin, e.g. in southern Kyrgyzstan,

1073 the situation is different: There, non-marine siliciclastic rocks similar to those of the Gurud

1074 Formation characterize the complete Jurassic succession (pers. obs.). A direct comparison is,

1075 however, hampered by still missing chronostratigraphic information. Thus, it is not clear

1076 whether the several-thousand-metres-thick siliciclastic succession cropping out in the Jerzy

1077 River area near the border to China represents the whole or only part of the Jurassic Period. A

1078 palynological analysis to clarify this problem is in progress. 
1082 The Afghan-Tajik and Amu Darya basins are situated on the southern part of the Turan 1083 Platform. Their early extensional history during Late Permian - Early Triassic is not well 1084 known as these deposits, possibly filling grabens, are deeply buried. Permian and Triassic

1085 sediments occur on the southern margins of the Amu-Darya and Afghan-Tajik basins in south 1086 Turkmenistan and North Afghanistan where they unconformably overlie Palaeozoic beds 1087 (Brookfield \& Hashmat 2001; Ulmishek 2004; Klett et al. 2006; Abdullah et al. 2008). The 1088 narrow grabens were linked to intra-arc and back-arc extension behind subduction of the 1089 Palaeotethys towards the North, below the Turan Platform.

1090 Several Cimmerian blocks became detached from Gondwana during the Permian and 1091 collided with Eurasia leading to the formation of the Eo-Cimmerian unconformity and the Eo1092 Cimmerian belt (Zanchi et al. 2009; Zanchetta et al. 2013 and references herein). First the 1093 Iranian blocks collided in Late Triassic, followed by the Central Afghanistan and Central 1094 Pamir blocks at the end of the Triassic, accounting for a slightly younger unconformity, 1095 deformation and post-collisional magmatism towards the East (Klett et al. 2006; Zanchi et al. 1096 2009, 2012; Zanchetta et al. 2013; Siehl 201X). From the eastern part of Iran and the Amu

1097 Darya Basin towards the East, Palaeozoic and Triassic sediments are unconformably covered 1098 by Jurassic sediments (Brookfield \& Hashmat 2001; Ulmishek 2004; Klett et al. 2006; 1099 Abdullah et al. 2008; Zanchi et al. 2009, 2012; Zanchetta et al. 2013; Siehl 201X). Eo1100 Cimmerian reliefs were uplifted and eroded, providing Jurassic siliciclastic sediments that 1101 filled the new basins (Amu Darya and Afghan-Tajik basins) created by extensional tectonics 1102 (Brookfield \& Hashmat 2001; Ulmishek 2004; Klett et al. 2006; Brunet et al. 201X).

1103 The northwestern Afghan-Tajik Basin of the study area in southern Uzbekistan was 1104 shaped by this framework of horst and grabens created in the Early Jurassic as result of the 1105 dismembering of a part of the Eo-Cimmerian orogenic belt. Here no Triassic sedimentary 1106 rocks have been encountered; sedimentation started in the Toarcian and was probably 1107 diachronous. Extensional tectonics induced active tectonic subsidence. This explains the 1108 observed variations in thickness, the progressive deepening, and the onset of marine 1109 conditions in the Late Bajocian. The area of the Kugitang Mountains occupied a deep part of 1110 the extensional margin which shallowed towards the North-East. The extension ceased during 1111 the Middle Jurassic to give way to a more continuous thermal subsidence. 
1113 basins formed a single basin (Ulmishek 2004). The Late Palaeogene-Neogene collision of the

1114 Indian Plate with the Eurasian Plate uplifted the southern margins of the basins, mainly

1115 shaped the southwestern Gissar range, which divided the northern portion into the two basins,

1116 and strongly deformed the Afghan-Tajik Basin, situated nearest to the Pamirs (Klett et al.

1117 2006).

\section{Conclusions}

The Lower Jurassic to Lower Callovian sedimentary succession of the Afghan-Tajik Basin in southern Uzbekistan records the history of an extensional basin with pronounced topography. The non-marine siliciclastic rocks overlying the Palaeozoic basement rocks represent environments ranging from braided and meandering streams to floodplains, swamps, and lakes. The latter are either short-lived or long-ranging and wide-spread. Their sediments are commonly arranged in progradational cycles. Plant growth was ubiquitous as is documented by rootlets, coal layers, wood pieces and plant debris and indicates a humid climate. In the Late Bajocian the sea flooded the basin. Initially, the sedimentation regime remained siliciclastic, representing storm-influenced ramp environments that shallowed into a deltaic setting, locally with paralic coal. With the return to a storm-influenced ramp setting the siliciclastic sediment influx decreased and mixed carbonate siliciclastic sediments were deposited.

Part of the Middle Bathonian time interval is marked by sediment starvation. The Late

1135 Bathonian to Early Callovian interval represents an outer ramp to basinal setting,

1136 characterized by an increasing carbonate content of the sediment. It is followed by a thick

1137 carbonate unit, which is beyond the scope of this study. The marine unit is composed of

1138 metre-scale parasequences and corresponds to two third-order depositional sequences.

1139 Marked lateral thickness changes of the investigated succession point to a pronounced 1140 relief of the basement. Maximum subsidence occurred from the Kugitang Mountains in the 1141 South to the Baysun area in the North, whereas further north in the Gissar Mountains and 1142 north of Denau strongly reduced thicknesses with a dominance of coarse-grained fluvial 1143 channel deposits indicate the margin of the basin. 

to Early Callovian time interval is interpreted to partly reflect a reduced topography of the hinterland, partly a change in climate from humid to arid. A similar shift in sediment composition occurs also in central-east Iran, the Alborz Mountains, Kopet Dagh, and Binalud Mountains of Iran and demonstrates that this climate shift was of at least regional significance. Furthermore, flooding of these Iranian basins and the Afghan-Tajik Basin around the Early-Late Bajocian boundary suggests a more or less synchronous active subsidence and some shared geodynamic history.

We would like to thank I. Sidorova, B. Nurtaev, D.P. Ishniyazov, Dmitriy Mordvintsev, Matthias Alberti, Martin Regelsberger, Johann Schnyder, and Raphael Bourillot for assistance in the field, Eric Barrier for discussions, and Martin Regelsberger, Golda Schugmann, Matthias Alberti, and Manja Hethke for drafting the diagrams. Vitali Mitta kindly helped with obtaining some of the Russian literature. Kazem Seyed-Emami kindly identified the ammonites. The comments of two anonymous reviewers helped to improve the manuscript.

References

AbDullaev, G. S. \& Mirkamalov, H. H. 1998. Unification stratigraphic nomenclature of commercial horizons of carbonate formations of the Jurassic, southern and southwestern Uzbekistan. Journal of Uzbek Oil and Gas, 1998(4), 1316.

Abdullah, S. H., Chmyriov, V. M. \& Dronov V. I. (eds) 2008. Geology and Mineral

1167 Resources of Afghanistan. 2 Volumes. British Geological Survey Occasional Publication,

1168 15. http://www.bgs.ac.uk/downloads/browse.cfm?sec=7\&cat=83

1169 Afshar-Harb, A. 1994. Geology of the Koppet Dagh. Geological Survey of Iran, Report, 11, $1170 \quad 1275$ (in Farsi).

Aigner, T. 1979. Schill-Tempestite im Oberen Muschelkalk (Trias, SW-Deutschland). Neues Jahrbuch für Geologie und Paläontologie, Abhandlungen, 157, 326-343.

1174 Muschelkalk limestones (Middle Trias, SW-Germany. In: EINSELE, G. \& SEILACHER A.

1175 (eds) Cyclic and event stratification. Springer, Berlin, Heidelberg, 180198. 
1176

1177

1178

1179

1180

1181

1182

1183

1184

1185

1186

1187

1188

1189

1190

1191

1192

1193

1194

1195

1196

1197

1198

1199

1200

1201

1202

1203

1204

1205

1206

1207

1208

1209

Aigner, T. \& ReINECK, H.-E. 1982. Proximality trends in modern storm sands from the Helgoland Bight (North Sea) and their implications for basin analysis. Senckenbergiana Maritima, 14, 183215.

BArrier, E. \& VRIElynck, B., 2008. Palaeotectonic Maps of the Middle East. TectonoSedimentary-Palinspastic Maps from Late Norian to Piacenzian. Commission for the Geological Map of the World (CGMW)/UNESCO. Atlas of 14 maps, scale 1/18 500000.

Brookfield, M. E. \& Hashmat, A. 2001. The geology and petroleum potential of the North Afghan platform and adjacent areas (northern Afghanistan, with parts of southern Turkmenistan, Uzbekistan and Tajikistan. Earth-Science Reviews, 55, 4171.

Brunet, M.-F., Korotaev, M. V., Ershov, A. V. \& Nikishin, A. M. 2003. The South Caspian Basin: a review of its evolution from subsidence modelling. Sedimentary Geology, 156, 119-148.

Brunet, M.-F., Shahidi, A., BARrier, E., MÜller, C. \& SAÏDI, A. 2007. Geodynamics of the South Caspian Basin southern margin now inverted in Alborz and Kopet-Dagh (Northern Iran). Geophysical Research Abstracts, European Geosciences Union, Vienna, 9, 08080. http://www.cosis.net/abstracts/EGU2007/08080/EGU2007-J-08080.pdf

Brunet, M.-F., Ershov, A. V., Korotaev, M. V., Mordvintsev, D. O., Sidorova, I. P. \& BARRIER, E. 201X. Late Palaeozoic and Mesozoic evolution of the Amu Darya Basin (Turkmenistan, Uzbekistan). This volume.

Carmeille, M., Bourillot, R., Barrier, E., Fürsich, F., Thierry, J., Pellenard, P., Schnyder, J., AuxiÈtre, J.L., Munsch, H., Mortvintsev, D. \& Sidorova I. 2014. Facies, architecture and diagenesis of middle to upper Jurassic carbonates in the Ghissar Range (Uzbekistan). Abstract EGU meeting Vienna.

Dzhalilov, M. R., Alekseev, M. N., Andreev, Yu. N. \& Salibaev, G. Kh. 1982. Mesozoic and Cenozoic deposits of the northern part of the Afghano - Tajik basin. ESCAP Atlas of Stratigraphy. III. United Nations Mineral Resources Development Series No. 48, 131137.

EgAmberdiev M. E. \& IshniYAzOv D. P. 1990. Comparative lithologic and facialpalaeogeographic characteristics of lower and middle Jurassic deposits of South Uzbekistan and North Afghanistan with hypothetical resources evaluation of coalfield, Final Report (1986-1990) by the Institute of Geology \& Geophysics of Academy of Sciences of Uzbekistan, Tashkent, 2 volumes (in Russian).

FLÜGEL, E. 2010. Microfacies of carbonate rocks. Analysis, interpretation and application. Springer, Berlin, Heidelberg, 984 p. 
FÜRSICH, F. T. 1977. Corallian (Upper Jurassic) marine benthic associations from England and Normandy. Palaeontology, 20, 337385.

1212 FÜRSICH, F. T. \& WERNER, W. 1986. Benthic associations and their environmental

1213 significance in the Lusitanian Basin (Upper Jurassic, Portugal). Neues Jahrbuch für

1214 Geologie und Paläontologie, Abhandlungen, 172, 271329.

1215 FÜrsich, F. T., Wilmsen, M., SEyed-Emami, K. \& Majidifard, M. R. 2009a.

1216 Lithostratigraphy of the Upper Triassic - Middle Jurassic Shemshak Group of Northern

1217 Iran. In: Brunet, M.-F., Wilmsen, M. \& GRANATH, J. W. (eds) South Caspian to Central

1218 Iran Basins. Geological Society, London, Special Publications, 312, 129160.

1219 FÜrsich, F. T., Wilmsen, M., SeYed-EMAMi, K. \& MAJidifard, M. R. 2009b. The Mid-

1220 Cimmerian tectonic event (Bajocian) in the Alborz Mountains, Northern Iran: evidence of

1221 the break-up unconformity of the South Caspian Basin. In: BRUNET, M.-F., WiLMSEN, M.

1222 \& Granath, J. W. (eds) South Caspian to Central Iran Basins. Geological Society,

$1223 \quad$ London, Special Publications, 312, 189203.

1224 FÜrsich, F.T., Oschmann, W., Pandey, D.K., Jaitly, A.K., Singh, I.B. \& LiU, C.

1225 2004. Palaeoecology of Middle to lower Upper Jurassic macrofaunas of the

1226 Kachchh Basin, western India: an overview. Journal of the Palaeontological Society

1227 of India, 49, 126.

1228 Gomolitzky, N. P. \& Lobanova, A. V. 1969. K stratigrafii yurskikh otlozheniy Angrena.

1229 Sovetskaya geologiya, 9, 110115 (On the stratigraphy of the Jurassic sediments of

1230 Angren, in Russian).

1231 Hardenbol, J., Thierry, J., FArley, M.B., Jaquin, Th., De Graciansky, P.-C. \& Vail, P.R.

1232 1998. Mesozoic and Cenozoic sequence chronostratigraphic framework of European

1233 basins. In: DE GRACIANSKY, P.-C., HARdenbol, J., Jaquin, TH. \& VAil, P.R. (eds)

1234 Mesozoic-Cenozoic sequence stratigraphy of European basins. Society of Economic

1235 Paleontologists and Mineralogists, Special Publication, 60, 763 781, and chart

1236 supplements.

1237 Kim, A. I., Salimova, F. A., Abduasimova, I. M. \& Meshchankina, N. A. (eds) 2007.

1238 Palaeontological Atlas of Phanerozoic faunas and floras of Uzbekistan. Volume II.

1239 Mesozoic and Cenozoic (Jurassic, Cretaceous, Palaeogene). Republic of Uzbekistan State

$1240 \quad$ Committee on Geology and Mineral Resources, Tashkent.

1241 Klett, T. R., UlmisheK, G. F., Wandrey, C. J., Agena, W. F. \& U.S. GeOlogical Survey-

1242 AfGHANistan Ministry OF Mines AND INDUSTRy JOINT OIL MAND GAs ResourCe

1243 Assessment TEAM. 2006. Assessment of undiscovered technically recoverable 
conventional petroleum resources of northern Afghanistan. U.S. Geological Survey OpenFile Report, 2006-1253, 1237.

Klett, T. R., Schenk, C. J., WANDrey, C. J., Charpentier, R. R., Brownfield, M. E.,

\section{Pitman, J. K., Pollastro, R. M., CoOK, T. A. \& Tennyson, M.E. 2012. Assessment of undiscovered Oil and gas resources of the Amu Darya Basin and Afghan-Tajik Basin} provinces, Afghanistan, Iran, Tajikistan, Turkmenistan, and Uzbekistan, 2011. U.S. Department of the Interior, U.S. Geological Survey, Fact Sheet 2011-3154.

KRYMHOLTS, G. YA. \& ZAKHAROV, E. V. 1971. Bathonian ammonites of Kugitang. In: Shaykubov, T. SH. (ed) Paleontological substantiation of reference sections of the Jurassic system in Uzbekistan and adjacent areas. Leningrad, Nedra, 440 (in Russian).

Krymholts, G. Ya., Mesezhnikov, M. S. \& Westermann, G. E. G. (eds) 1988. The Jurassic ammonite zones of the Soviet Union. Geological Society of America, Special Paper, 223, 1-116.

Miall, A. D. 1996. The geology of fluvial deposits. Springer, Berlin.

MitTA, V. V. 2001. Distribution of the Bajocian-Bathonian ammonites in the South-West chains of Hissar Range. Hantkeniana, 3, 105-129.

MitTA, V. V.\& Besnosov, N. V. 2007. Jurassic system Cephalopods. In: KIM, A. I., Salimova, F. A., Abduasimova, I. M. \& Meshchankina, N. A. (eds) PaIaeontological Atlas of Phanerozoic faunas and floras of Uzbekistan. Volume II, Mesozoic and Cenozoic. Republic of Uzbekistan State Committee on Geology and Mineral Resources, Tashkent, 2641.

MontenAt C., 2009. The Mesozoic of Afghanistan. GeoArabia, 14, 1, 145-208.

Mutti, E., Tinterri, R., Benevelli, G., Di Biase, D, \& Cavanna, G. 2003. Deltaic, mixed and turbidite sedimentation of ancient foreland basins. Marine and Petroleum Geology, 20, 733755.

MYrow, P. M. 1992. Pot and gutter casts from the Chapel Island Formation, Southeast Newfoundland. Journal of Sedimentary Research, 62, 9921007.

Nikolaev, V. G. 2002. Afghan-Tajik depression: Architecture of sedimentary cover and evolution. Russian Journal of Earth Sciences, 4, 399-421.

Reading, H. G. \& Collinson, J. D. 1996. Clastic coasts. In: Reading, H. G. (ed) Sedimentary environments. Blackwell's, London, 154231.

RENZHINA, E. A. \& FoKINA, N. I. 1978. Terrigenous marine deposits and conditions of their sedimentation in western Uzbekistan. VNIGNI Transactions, 209, 7690 (in Russian). 
RESOLUTIONS OF THE INTERDEPARTMENTAL STRATIGRAPHICAL MEETING ON THE MESOZOIC OF MIDDLE ASIA. 1977. [Resheniya Mezhvedomstvennogo stratigraficheskogo soveshchaniya po mezozoyu Srednei Asii (Samarkand, 1971)]. VSEGEI, Leningrad, 47 p. (in Russian).

SCHAETZL, R. \& ANDERSON, S. 2005. Soils. Genesis and geomorphology. Cambridge University Press, Cambridge.

SEYED-EMAMI, FÜRSICH, F.T. \& SCHAIRER, G. 2001. Lithostratigraphy, ammonite faunas and palaeoenvironments of Middle Jurassic strata in north and central Iran. Newsletters on Stratigraphy, 38, 163-184.

ShayAKubOv, T. S. (Eds.) 1998. Geological Map of Uzbekistan, scale 1:500000 (in Russian).

Shayakubov, T. Sh. \& Dalimov, T. N. (eds) 1998. Geology and minerals of the Republic of Uzbekistan, Tashkent, National University of Uzbekistan, 723 p.

SHINN, E. 1983. Birdseyes, fenestrae, shrinkage pores, and loferites: a re-evaluation:Journal of Sedimentary Petrology, 53, 619-628.

SIEHL, A. 201X. Structural setting and evolution of the Afghan orogenic segment - a review. This volume.

Stampfli, G. M. \& Borel, G. D. 2002. A plate tectonic model for the Paleozoic and Mesozoic constrained by dynamic plate boundaries and restored synthetic oceanic isochrons. Earth and Planetary Science Letters, 196, 1733.

TAHERI, J., FÜrSICH, F. T. \& WILMSEN, M. 2009. Stratigraphy, depositional environments and geodynamic significance of the Upper Bajocian-Bathonian Kashafrud Formation, NE Iran. In: Brunet, M.-F., Wilmsen, M. \& Granath, J. W. (eds) South Caspian to Central Iran Basins. Geological Society, London, Special Publications, 312, 205218.

TeVeleV, A. V. \& GeORGIEVsKII, B. V. 2012. Deformation history and hydrocarbon potential of the Southwestern Gissar Range (Southern Uzbekistan). Moscow University Geology Bulletin, 67, 340352.

UlmisheK, G. F. 2004. Petroleum geology and resources of the Amu Darya Basin, Turkmenistan, Uzbekistan, Afghanistan, and Iran. U.S. Geological Survey Bulletin, 2201H, 132.

VaKhrameev, V. A., IlJina, V. I. \& Fokina,N. I. 1988. Subdivision of the continental Jurassic based on plants. In: KRYMHOLts, G. YA., MesezhniKov, M. S. \& WestermanN, G. E. G. (eds) 1988. The Jurassic ammonite zones of the Soviet Union. Geological Society of America, Special Paper, 223, 6372. 
WAlKer, R. G. \& Plint, A. G. 1992. Wave-and storm-dominated shallow marine system. In: WALKer, R. G. \& JAMES, N. P. (eds) Facies models: Response to sea level change. Geological Association of Canada, St. John's, 219238.

Wilmsen, M., FÜrsich, F. T., Seyed-EMAmi, K. \& MAJidifard, M. R. 2009a. The Cimmerian Orogeny in Iran - a foreland perspective. Terra Nova, 21, 211218.

Wilmsen, M., FÜrsich, F. T., Seyed-Emami, K. \& Majidifard, M. R. 2009b. An overview of the stratigraphy and facies development of the Jurassic System on the Tabas Block, east central Iran. In: BRUNET, M.-F., WilmSEn, M. \& GranAth, J. W. (eds) South Caspian to Central Iran Basins. Geological Society, London, Special Publications, 312, 323-343.

Zanchetta, S., Berra, F., Zanchi, A., Bergomi, M., Caridroit, M., Nicora, A., Heidarzadeh, G. 2013. The record of the Late Palaeozoic active margin of the Palaeotethys in NE Iran: Constraints on the Cimmerian orogeny. Gondwana Research, 24, 1237-1266.

Zanchi A., Zanchetta S., Berra F., Mattei M., Garzanti E., Molyneux S., Nawab A. \& SABOURI J. 2009. The Eo-Cimmerian (Late? Triassic) orogeny in north Iran. In: Brunet, M.-F., Wilmsen, M. \& Granath, J. W. (eds) South Caspian to Central Iran Basins. Geological Society, London, Special Publications, 312, 3155. 
1330 Captions of figures and tables

Fig. 1. Position of the study area in the framework of the Amu Darya and Afghan-Tajik basins (a) and section localities in southern Uzbekistan (b; see also Table 1). (a) Outlines of the Amu Darya and Afghan-Tajik basins according to Klett et al. (2012), topography background from USGS SRTM-3 http://dds.cr.usgs.gov/srtm/version2 1/SRTM3/. (b) Background topography from USGS SRTM3, geology according to geological map of Uzbekistan 1:500 000 (Shayakubov 1998). Jurassic rocks are shown in blue colour.

Fig. 2. Lithostratigraphic subdivisions (formations) of the Jurassic succession in southern Uzbekistan (after Krymholts et al. 1988, modified). H: Hettangian; PL: Pliensbachian; T: Toarcian; A: Aalenian; BAJOC: Bajocian; CALL: Callovian; O: Oxfordian; K: Kimmeridgian; T: Tithonian; CR: Cretaceous; L: Lower; M: Middle; U: Upper.

1344 Fig. 3. Section of the Jurassic succession near Shalkan, Kugitang Mountains. For position see

1345 Table 1 and Fig. 1, for key of symbols Fig. 4. Siliciclastic sediments: cl, clay; s, silt/siltstone;

1346 f, fine-grained sandstone; m, medium-grained sandstone; c, coarse-grained sandstone; $g$,

1347 gravelly sandstone; carbonate microfacies: m, mudstone; w/f, wackestone/floatstone; $\mathrm{p}$,

1348 packstone; g, grainstone; r, rudstone. K., Kugitang Formation.

Fig. 4. Key of symbols.

1352 Fig. 5. (a) Jurassic succession near Shalkan (see Fig. 3 for litholog). The arrow points to the

1353 top of the Palaeozoic metamorphic basement, the vertical wall is the Callovian-Oxfordian

1354 Kugitang Formation. Below is the softer Early Jurassic to early Callovian succession which is

1355 dominated by fine-grained, often poorly indurated siliciclastic sediments and therefore

1356 weathers more easily. (b) Jurassic succession at Panjab (see Fig. 7 for litholog). The lower

1357 part of the section corresponds to the Upper Bajocian - Lower Bathonian Degibadam

1358 Formation, the recessive middle part to the silty marl of the Baysun Formation. The vertical

1359 cliff is composed of limestones of the Kugitang Formation. (c) Succession of stacked fluvial

1360 sandstones displaying lateral accretion; basal part of the Shargun section (see Fig. 11 for

1361 litholog). The individual sandstone bodies are separated by thin, often lenticular,

1362 carbonaceous mudstone units. (d) Palaeosol (brown soil) overlying the Palaeozoic 
1363 metamorphic basement and followed by a sharp-based sandstone unit representing the fill of a

1364 small fluvial channel; Shalkan section. (e) Thin conglomerate overlying weathered

1365 metamorphic basement rocks west of Vuariz. (f) Upper part of the non-marine Jurassic

1366 succession, strongly reduced in thickness, at Vuariz. The figured succession consists mainly

1367 of fine-grained floodplain deposits, with occasional intercalations of carbonaceous lacustrine

1368 mudstones and fluvial channel sandstones. The transgressive surface at the top of the cliff is

1369 marked with an arrow. (g) Stacked fluvial channel sandstones separated by finer-grained

1370 floodplain deposits, south-west of the village Vuariz. (h) Transition from the marly-

1371 calcareous Baysun Formation to the thick-bedded limestones of the Kugitang Formation; Iron

1372 Gate section (see Fig. 10 for litholog).

1373

1374 Fig. 6. Section of the Jurassic succession at Vandob, Kugitang Mountains. For position see

1375 Table 1 and Fig. 1, for key of symbols Figs. 3, 4. TR, transgressive surface. K., Kugitang

1376 Formation.

1377

1378 Fig. 7. Section of the Jurassic succession at Panjab, northern Kugitang Mountains. For

1379 position see Table 1 and Fig. 1, for key of symbols Figs. 3, 4. K., Kugitang Formation.

1380

1381 Fig. 8. Section of the Jurassic succession at the Dalut Mine near the village Toda. For position

1382 see Table 1 and Fig. 1, for key of symbols Figs. 3, 4. c., ch., river channel; s., sw., swamp.

1384 Fig. 9. (a) Thick fluvial sandstone sharply overlain by fine-grained lake deposits; base of

1385 Dalut Mine section (Fig. 8). (b) Point bar deposits displaying lateral accretion: Dalut Mine

1386 section at 154 m (see Fig. 8 for litholog). (c) Rootlets in overbank sediments; Dalut Mine

1387 section. (d) Several coarsening-upward cycles of prodelta mudstones to bedded deltafront

1388 sandstones overlain by cross-bedded sandstones of a large distributary channel (upper two-

1389 fifths of section); Iron Gate section (see Fig. 10 at 70-115 m). (e) Sediments of the storm-flow

1390 dominated outer ramp. Between the argillaceous silty background sediments gutter casts

1391 (arrowed) and graded parallel-laminated sandstones are intercalated. Degibadam Formation of

1392 the Iron Gate section (see Fig. 10 at 18-27 m). (f) Hummocky cross-stratified sandstone;

1393 Degibadam Formation, Dalut Mine section. (g) The trace fossil Diplocraterion parallelum in

1394 the basal marine sandstone at the Shalkan section, first evidence of the marine transgression.

1395 (h) Angular unconformity between the Baysun Formation (below) and the Kugitang 
1396 Formation (above) near Khanjizza, north of Denau, indicative of synsedimentary tectonic

1397 movements produced by the slight tilting of a fault block.

Fig. 10. Section of the Jurassic succession near Derbent at the "Iron Gate". For position see Table 1 and Fig. 1, for key of symbols Figs. 3, 4. K., Kugitang Formation.

Fig. 11. Sections of the Jurassic succession at the Shargun Mine. For position see Table 1 and

Fig. 12. Section of the Jurassic succession near Sangardak. For position see Table 1 and Fig. 1, for key of symbols Figs. 3, 4.

Fig. 13. Sections of the Jurassic succession near Vuariz. For position see Table 1 and Fig. 1, for key of symbols Figs. 3, 4. D., Degibadam Fm.

1411 Fig. 14. Middle part of the Baysun Formation NE of Vuariz (Vuariz section IV; co-ordinates:

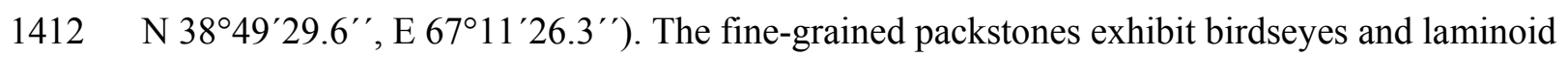

1413 fenestral fabrics characteristic of a peritidal environment. For key of additional symbols see

1414 Figs. 3, 4.

1416 Fig. 15. Examples of the main facies associations and their corresponding environments in the 1417 Jurassic of southern Uzbekistan. (a) Braided river deposits (Vuariz section at 0-14 m). (b)

1418 Meandering river deposits (Dalut Mine section at 225-231 m). (c) Flood-plain deposits (Dalut

1419 Mine section at 86-98 m). (d) Swamp deposits (Dalut Mine section at 263-268 m and 298-304

1420 m). (e) Offshore lake deposits (Shalkan section at 190-202 m). (f) Lake margin deposits

1421 (Shalkan section at 348-360 m). (g) Distributary channel deposits (Iron Gate section at 96-110

$1422 \mathrm{~m}$ ). (h) Delta front deposits (Vandob section at 370-379 m). (i) Prodelta - lower delta-front

1423 deposits (Iron Gate section at 63.5-75.5 m). (j) Tide-influenced inner ramp deposits (Panjab

1424 section at 40.5-52.5 m). (k) Protected inner ramp deposits (Panjab section at 34-46 m). (l)

1425 high-energy deposits of the inner to middle ramp (Panjab section at 94.5-99.5 m). (m) storm-

1426 wave dominated middle ramp (Vandob section at 503-513 m). (n) storm-flow dominated

1427 outer ramp (Dalut Mine section at 552-562 m). (o) Low-energy outer mixed carbonate-

1428 siliciclastic ramp deposits (Shalkan section at 740-745 m). (p) Condensed outer ramp deposits 
1429 (Shalkan section at 728-733 m). (q) Low-energy outer carbonate ramp (Vandob section at $1430 \quad 740-753 \mathrm{~m})$.

1432 Fig. 16. (a-f) Microphotographs of characteristic facies. Scale: $5 \mathrm{~mm}$. (a) Poorly sorted, 1433 immature, conglomeratic gravelly sandstone with abundant metamorphic clasts. Basal part of

1434 Gurud Formation, Shalkan section at 31.1 m (see Fig. 3). (b) Hummocky cross-stratified, very

1435 fine-grained sandstone with Chondrites at the base. Degibadam Formation, Shalkan section at 1436485 m (see Fig. 3). (c) Bioclastic fine-grained sandstone. Degibadam Formation, Vandob 1437 section at $528.5 \mathrm{~m}$ (see Fig. 6). (d) Onco-rudstone strongly affected by pressure solution. 1438 Baysun Formation, Panjab section at 221.2 m (see Fig. 7). (e) Onco-bio-floatstone with 1439 abundant coral fragments. Oncoids mainly immature. Baysun Formation, Panjab section at 1440288 m (see Fig. 7). (f) Bio-onco-floatstone with abundant shell fragments. Baysun Formation, 1441 Iron Gate section at $321.5 \mathrm{~m}$ (see Fig. 9). (g) Coarsening- and thickening-upward prodelta1442 deltafront succession. Degibadam Formation, Iron Gate section at 79-84 m (see Fig. 10).

1444 Fig. 17. Examples of cycles developed in the non-marine (a-d) and marine parts (e-j) of the 1445 Jurassic succession. (a) Fluvial cycle (braided stream) (Vandob section at 0-6 m)). (b) Fluvial 1446 cycle (meandering river) (Vuariz section at 17.5-23.7 m). (c-d) Progradational lacustrine 1447 cycles (Dalut Mine section; c: at 160-166 m; d: at 396-398 m). (e) Marine deltaic cycle 1448 (Vandob section at 370-388 m). (f) Progradational cycle of the storm-wave influenced ramp 1449 (Vandob section from 296-302 m). (g) Progradational cycle of the outer to middle siliciclastic 1450 ramp (Iron Gate section at 52.5-55 m). (h) Progradational cycle of the storm-flow influenced 1451 ramp (Iron Gate section at 16-20 m). (i-j) Cycles of the outer carbonate ramp (Panjab section; $1452 \mathrm{i}$ : at 263.8-268.2 $\mathrm{m}$; j: at 274-278 m). c to $\mathrm{j}$ represent parasequences.

1454 Fig. 18. Correlation of the Lower and Middle Jurassic succession within the study area. From 1455 Vandob (Kugitang Mts.) in the south to Iron Gate/Dalut Mine (Ghissar Spur) in the north the 1456 thickness is relatively uniform $(800-950 \mathrm{~m})$, but decreases distinctly towards the northeast 1457 (Shargun/Sangardak; $\sim 350 \mathrm{~m}$ ) and even more so towards Vuariz in the north $(<100 \mathrm{~m}$ for the 1458 non-marine part). The latter areas clearly represent the margin of the basin, which is 1459 supported by the coarser grain size of the sediment.

1461 Fig. 19. Schematic development of the sedimentary environments in the Afghan-Tajik Basin 1462 of southern Uzbekistan during the Early to early Late Jurassic. (a) During the Early Jurassic, 
1463 non-marine conditions prevailed. Close to the basin margin coarse-grained fluvial deposits

1464 were deposited, whereas extensive fine-grained lake deposits with coal swamps formed

1465 towards the centre of the basin. (b) Flooding of the basin in the Late Bajocian, increased

1466 levelling of the morphology of the hinterland, and a change from humid to more arid

1467 conditions led to gradual replacement of the siliciclastic regime by a mixed carbonate-

1468 siliciclastic regime. (c) By the late Callovian, a predominantly low-energy carbonate platform

1469 covered the study area. Sporadic influx of siliciclastic material remained confined to margins

1470 of the basin with a steep morphological gradient, whereas in deeper parts of the basin locally

1471 organic-rich mudstones formed.

1472

1473 Fig. 20. Sequence stratigraphic interpretation of the marine Middle Jurassic succession at the

1474 Iron Gate near Derbent. The siliciclastic to mixed carbonate-siliciclastic succession records

1475 two highstand systems tracts and one transgressive systems tract within the Late Bajocian

1476 Early Callovian time interval. Another transgressive systems tract, recording the initial

1477 flooding of the basin, is not exposed here. These 3rd-order sequences are composed of

1478 numerous parasequences (see Fig. 10). Note the large deltaic succession representing

1479 prodelta, delta front, and distributary channel in the lower part of the section.

1480

1481 Fig. 21. Comparison of Jurassic successions of Iran, southern Uzbekistan, and southwestern

1482 Kyrgyzstan. CEIM, Central East Iranian Microcontinent; U.J., Upper Jurassic.

1484 Table 1. Co-ordinates of the section localities.

1485 Table 2. Palaeoenvironments and their main features in the Lower to Middle Jurassic

1486 successions. ss: sandstone. 


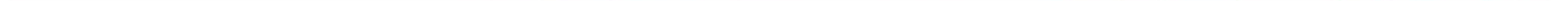


formations

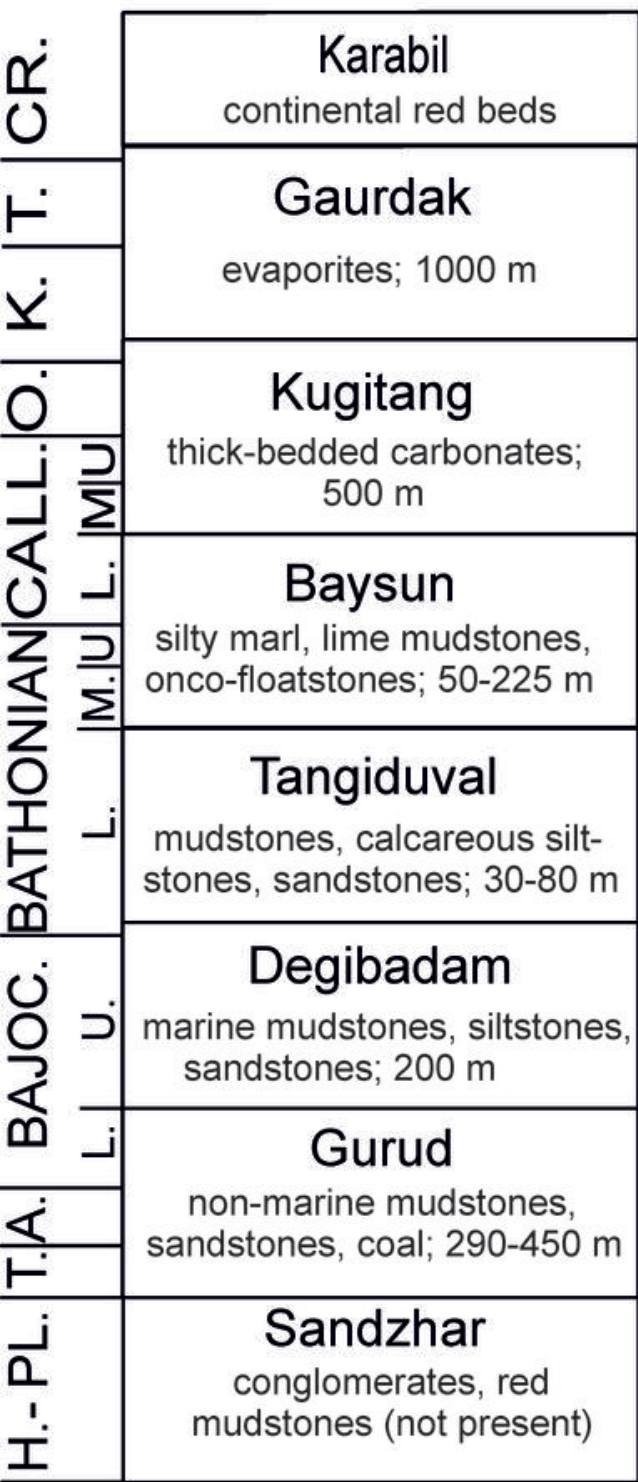




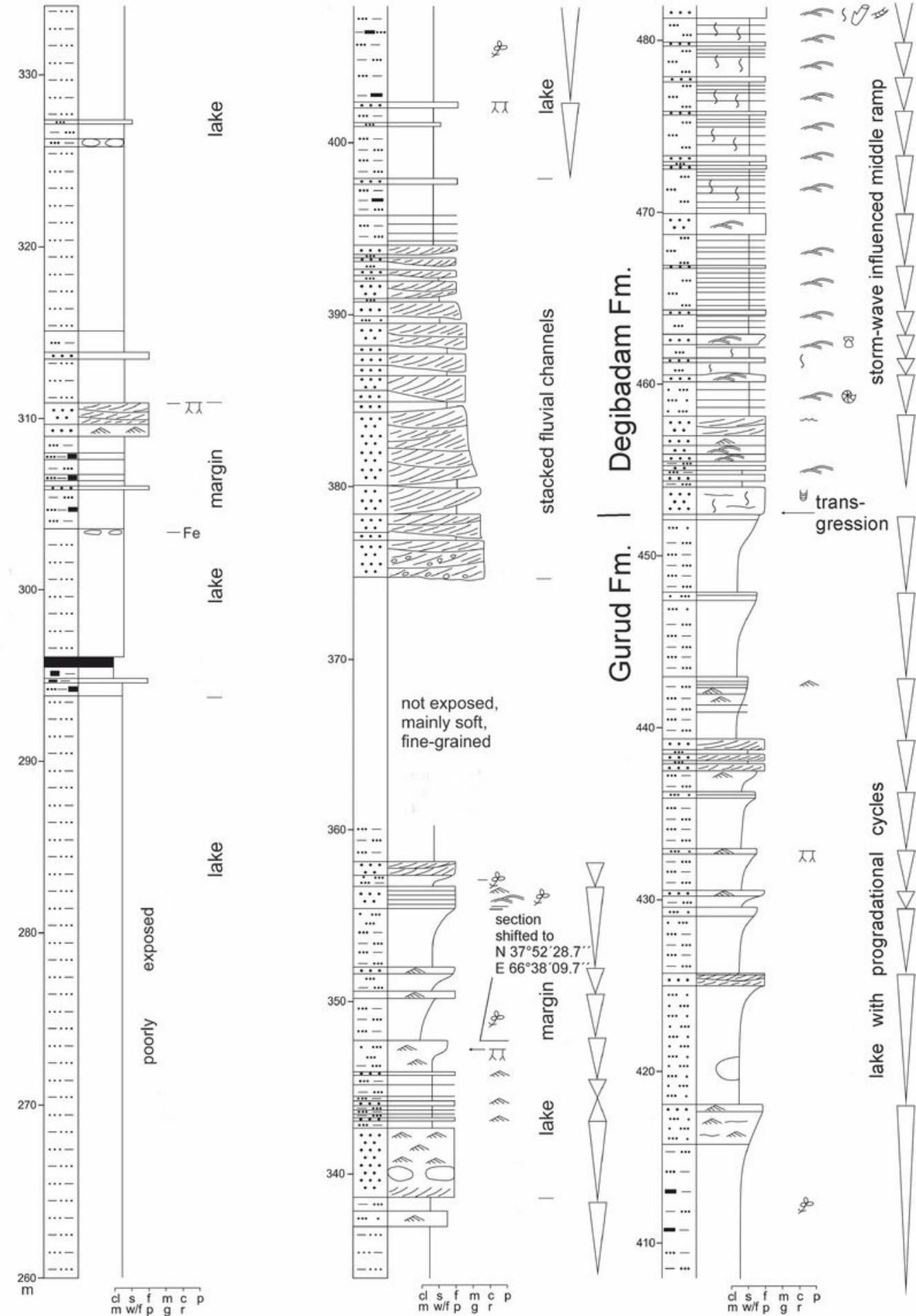




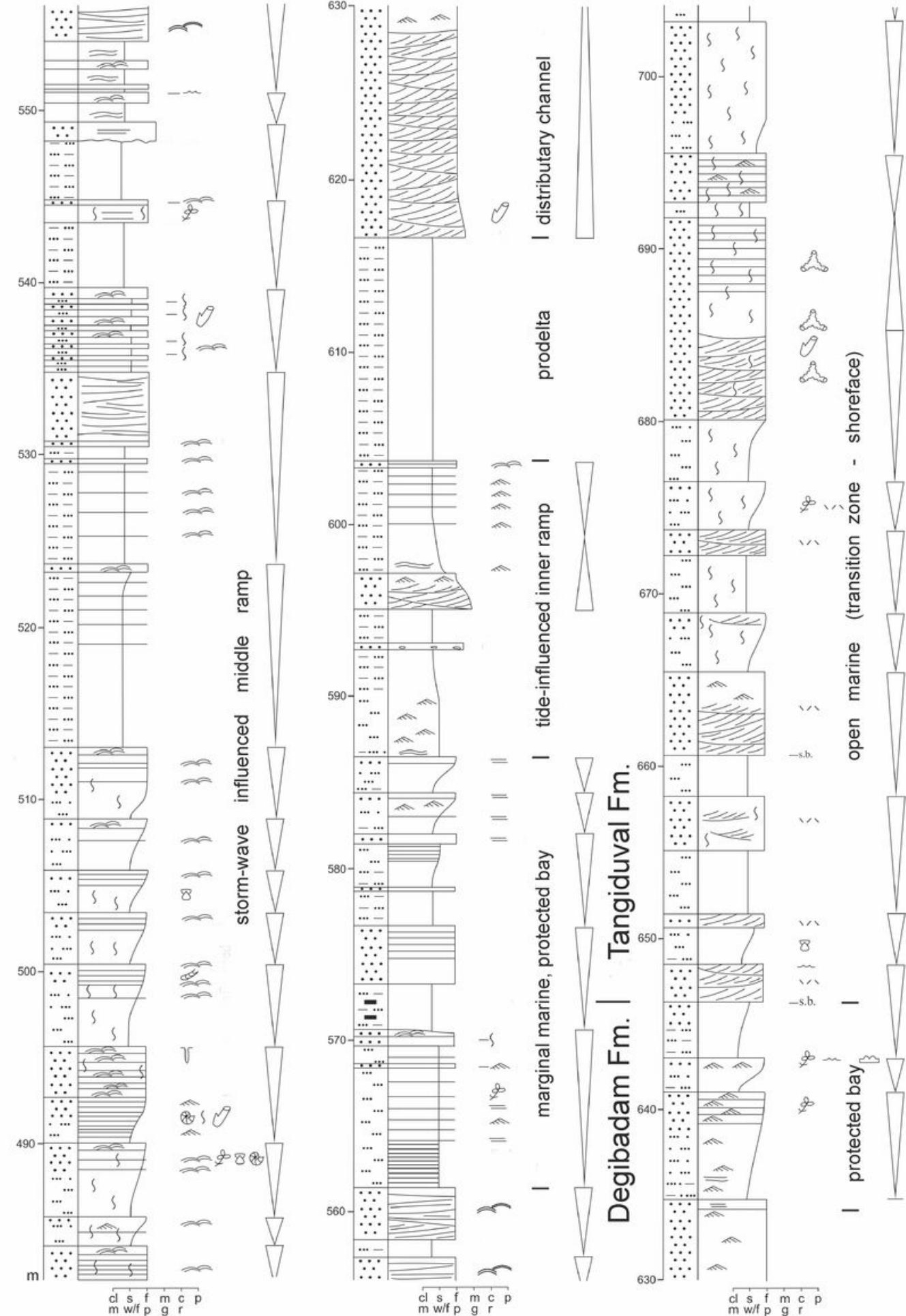



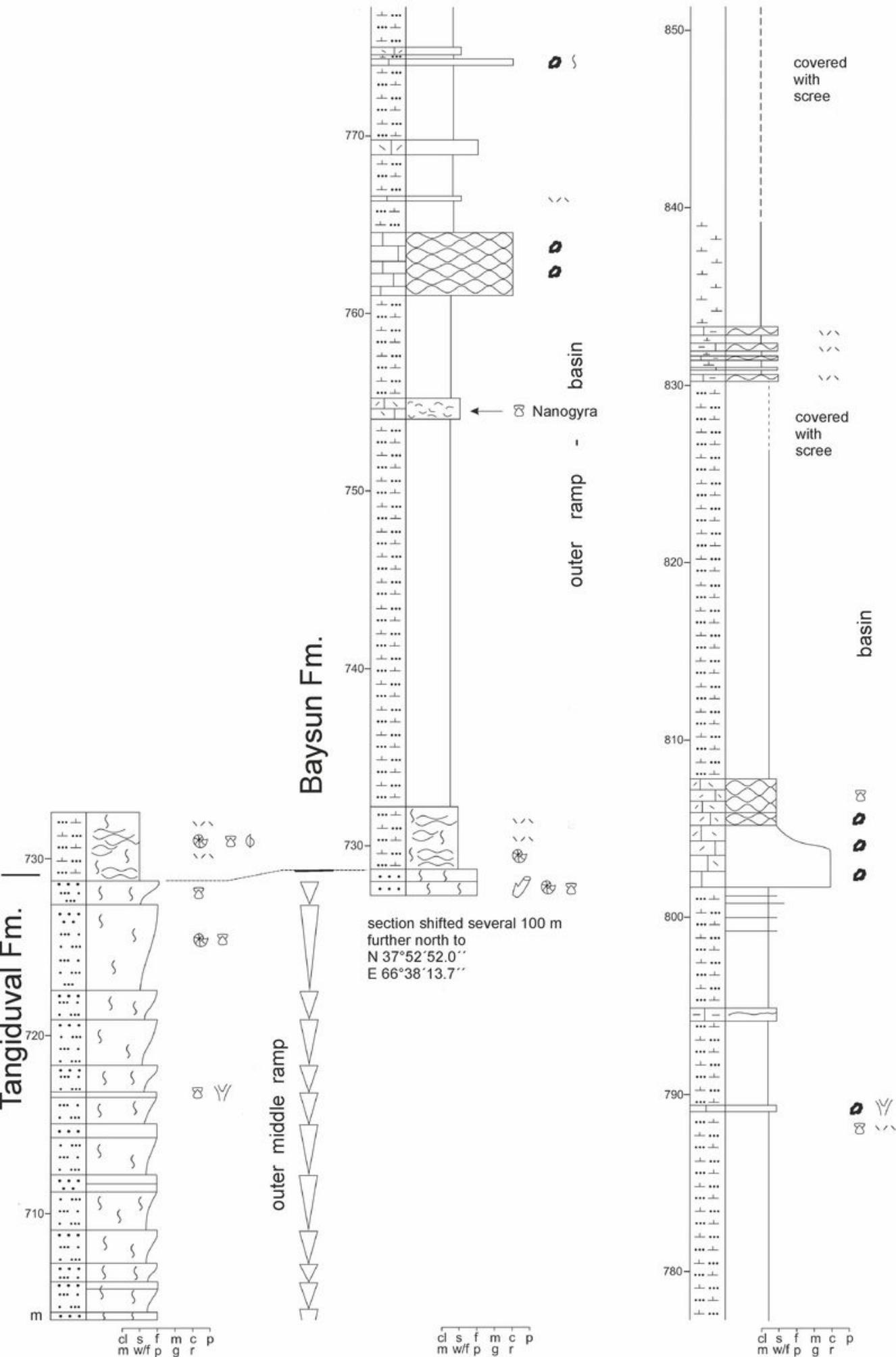


\section{limestone}

nodular limestone

$\frac{1}{1} \quad$ marlstone

$\perp \perp$ marl

$-^{-}-$clay

$\cdots$ silt/siltstone

$\because \therefore$ sandstone

${ }^{\circ}{ }^{\circ}$ pebbles

coal

_- highly carbonaceous

(2) oncoids

$\therefore$ ooids

11 bioclasts/shell debris

planar cross-bedding

large-scale trough

cross-bedding

$\approx$ hummocky cross-bedding

$\aleph$ ripple bedding
น oscillation ripples

= parallel lamination

$\checkmark$ gutter cast

ธu lenticular bedding

$\approx$ interlayered bedding

$\checkmark \smile$ flaser bedding

$\checkmark \sqrt{ }$ desiccation cracks

$\approx$ rubbly

concretion

$\sim$ flute cast

S shells/shell concentration

$\nabla$ bivalves

(2)) bivalves in growth position

gastropods

(6) ammonites

$\approx$ serpulids

$\diamond$ crinoids
( corals

$\checkmark$ belemnites

(1) brachiopods

$\eta$ wood fragments

$\beta$ wood logs

ff plants/plant debris

त久 root horizon

$\iiint$ bioturbation

Thalassinoides

Gyrochorte

Ophiomorpha

$\approx$ Planolites

$\circlearrowleft$ Scoyenia

Rhizocorallium irregulare

V Skolithos $\Delta \nabla \begin{aligned} & \text { fining-/coarsening } \\ & \text { upward }\end{aligned}$ 


\section{a}

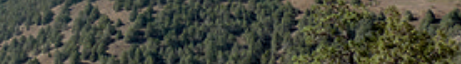

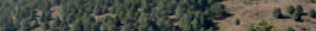

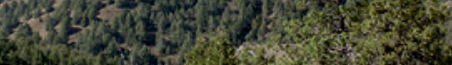

a 5 -
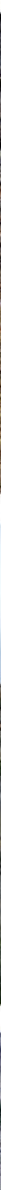

36) $3 \log ^{2}=$

(a)

ind for.t.

(3)

.

$-3+x+3=1$

S.

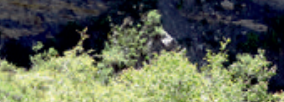

9

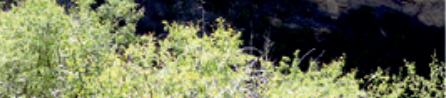

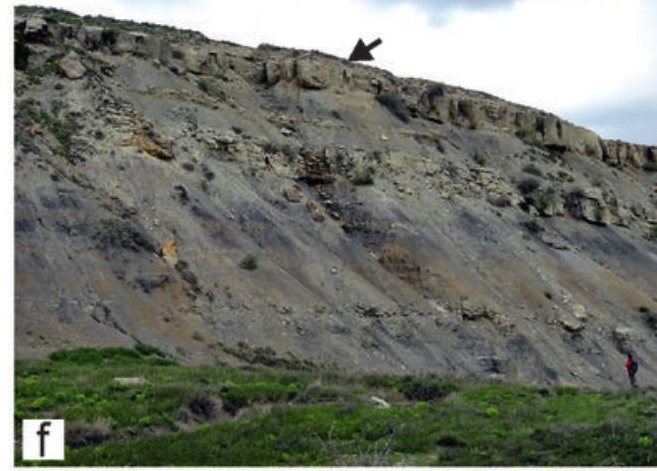

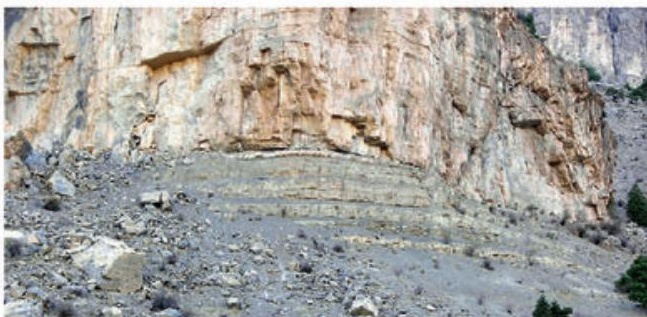

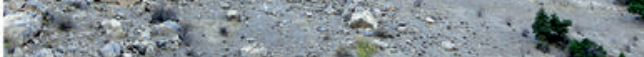

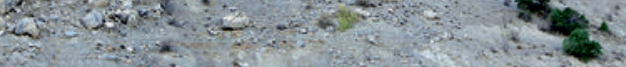

h 


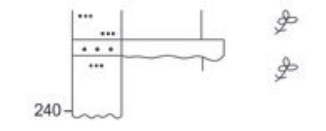

$175.5 \mathrm{~m}$ not exposed;

most of it argillaceous silt
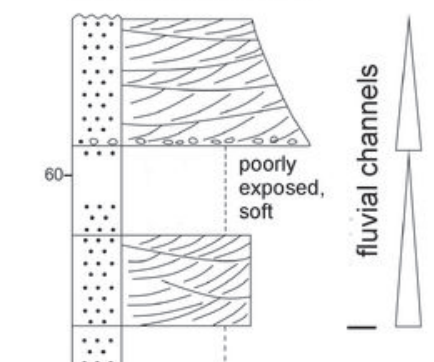

'ِ
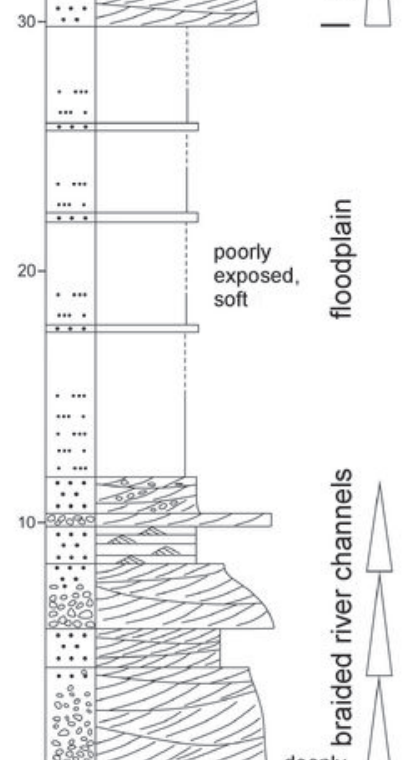

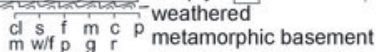

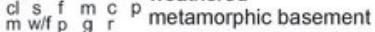





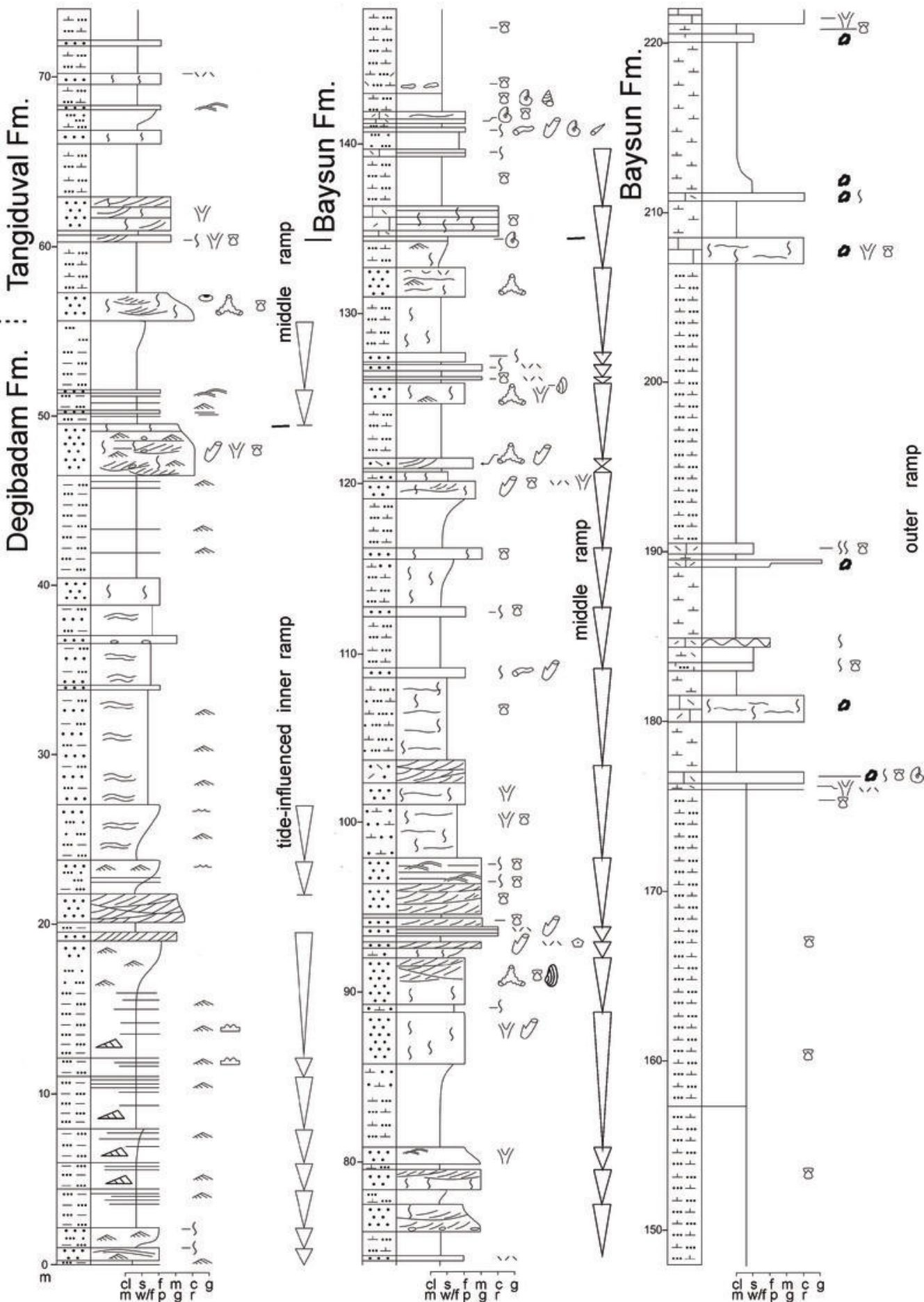




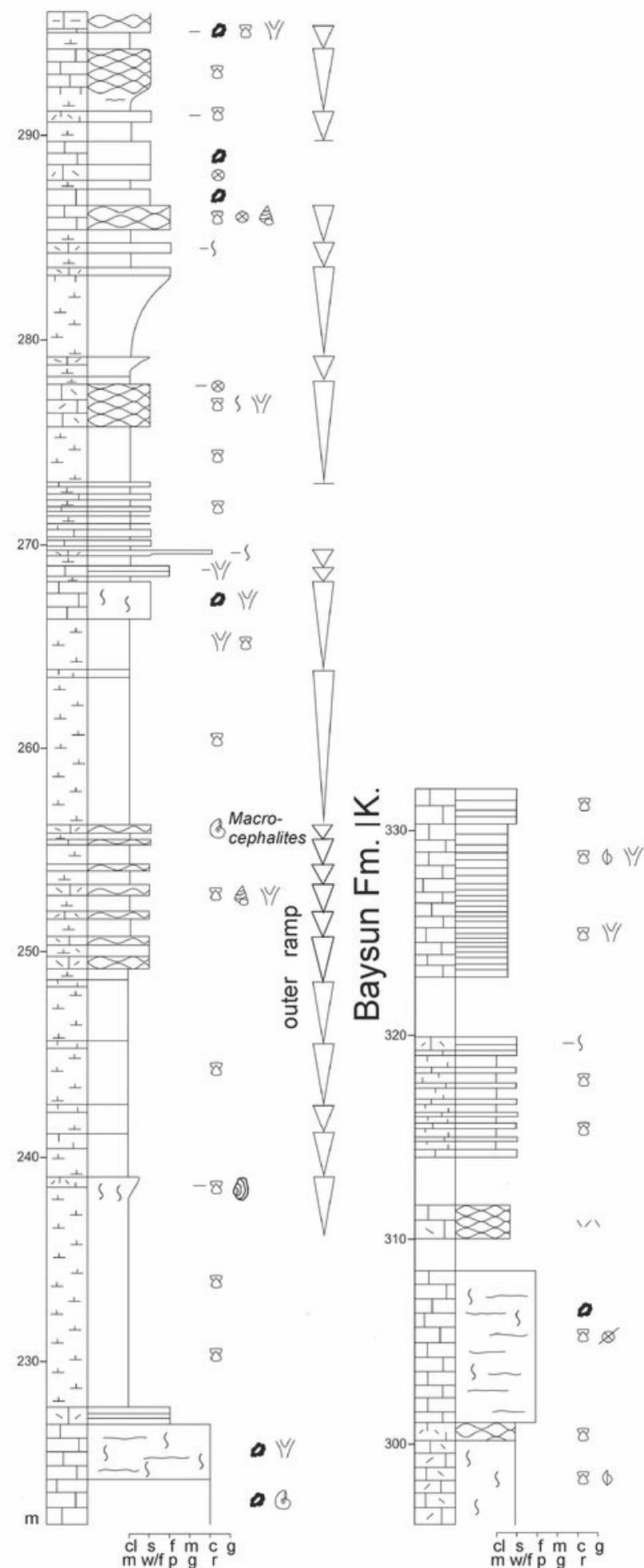




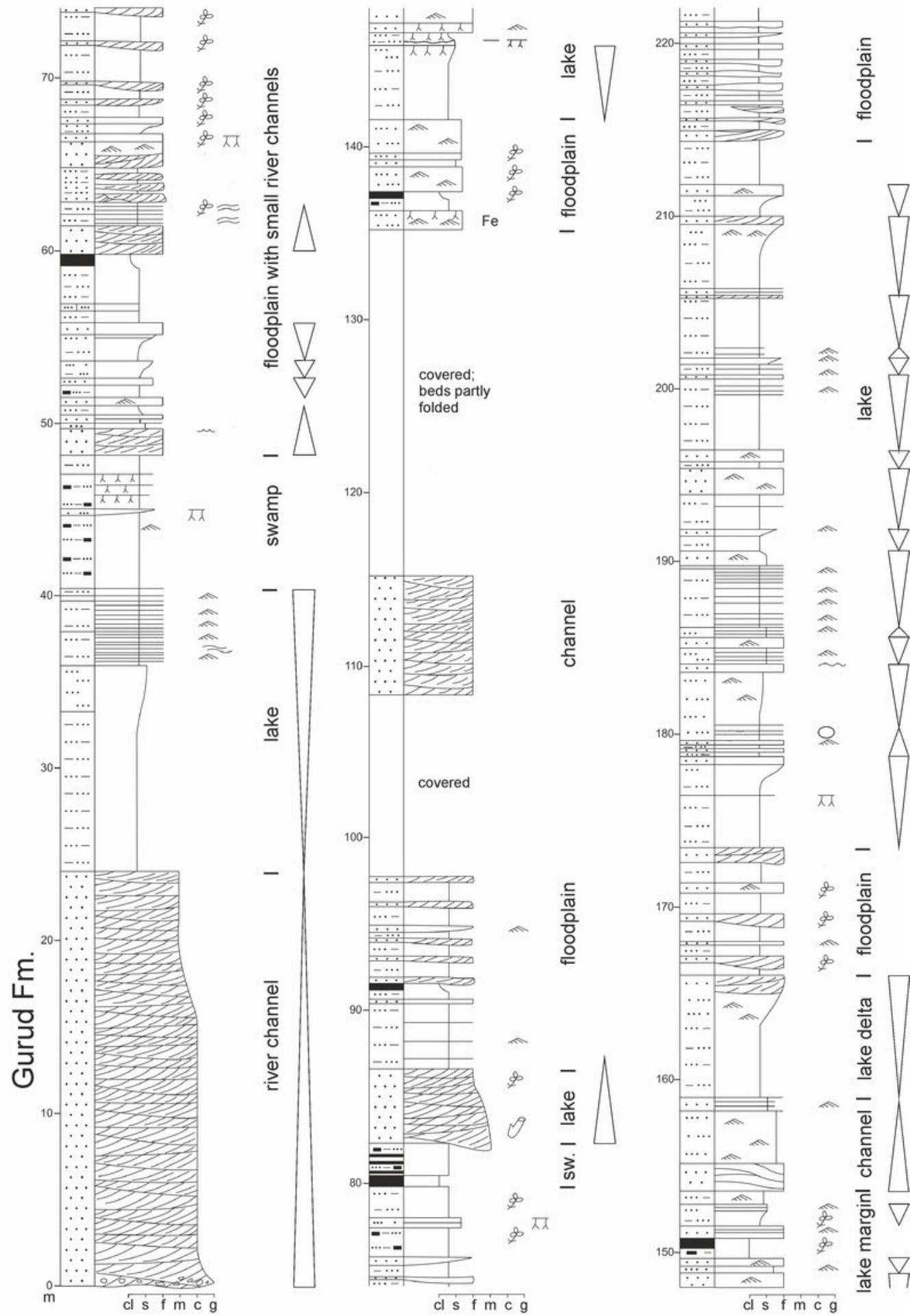




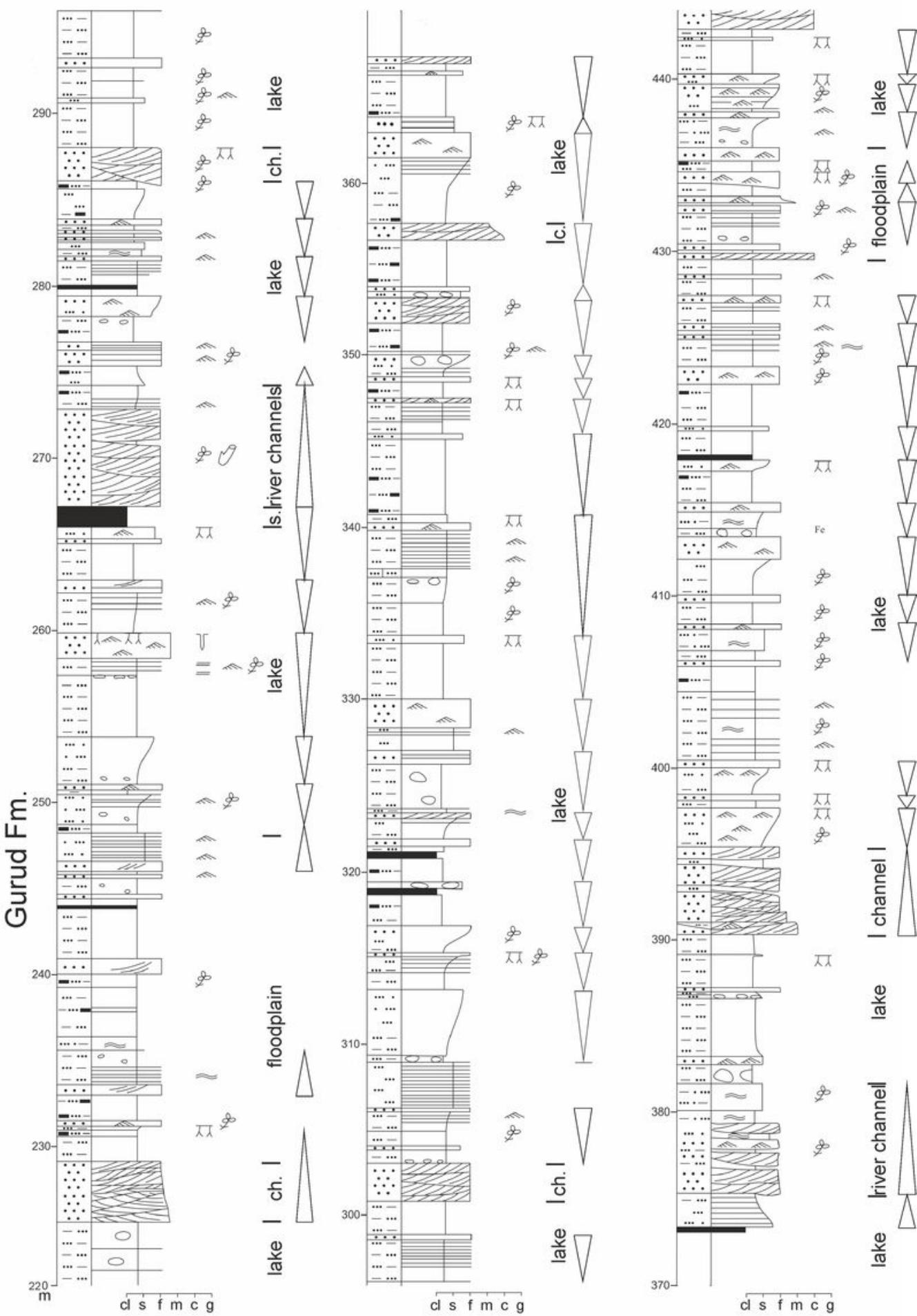




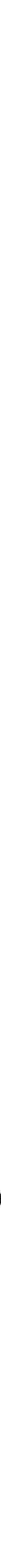



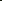


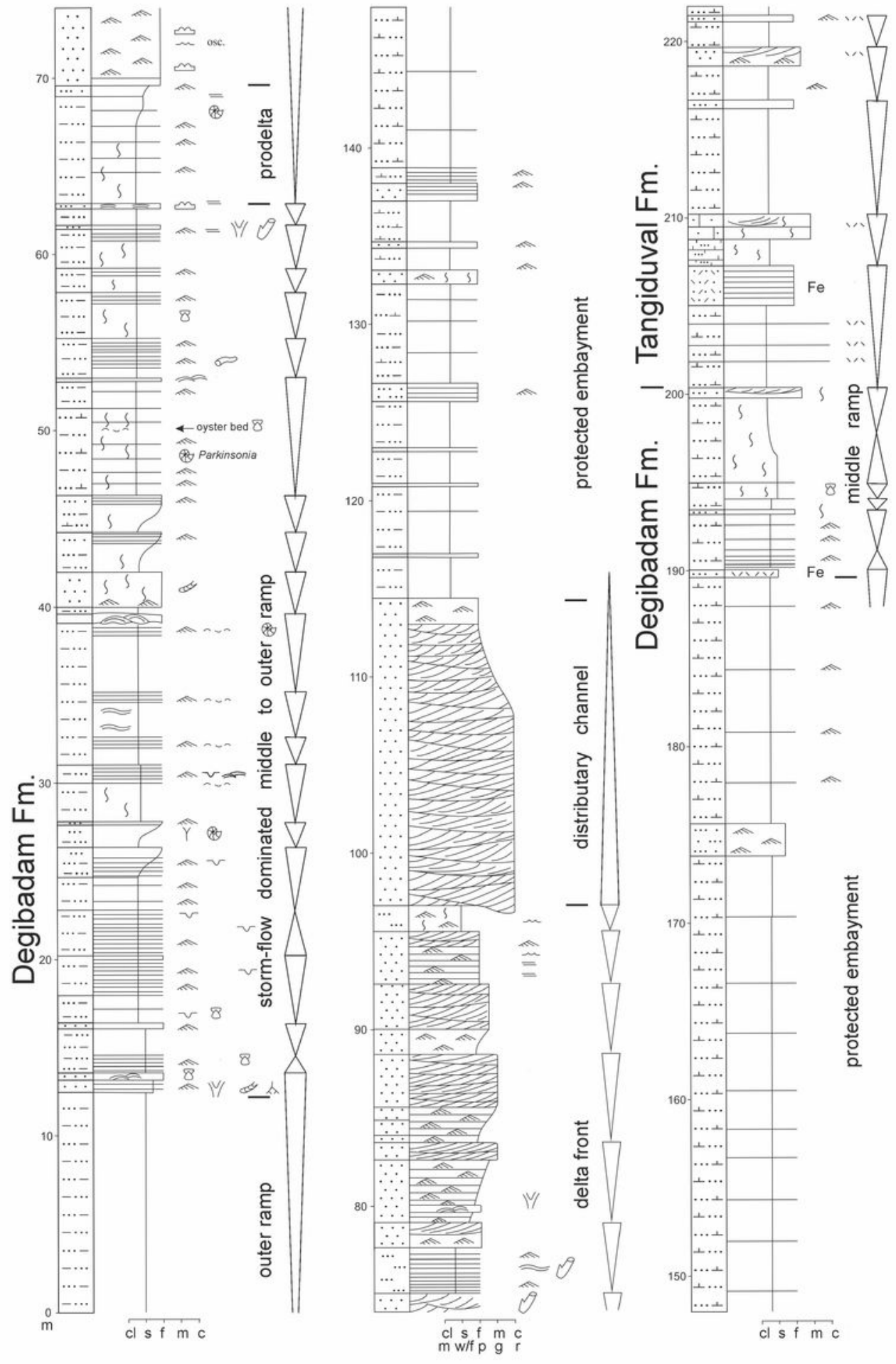




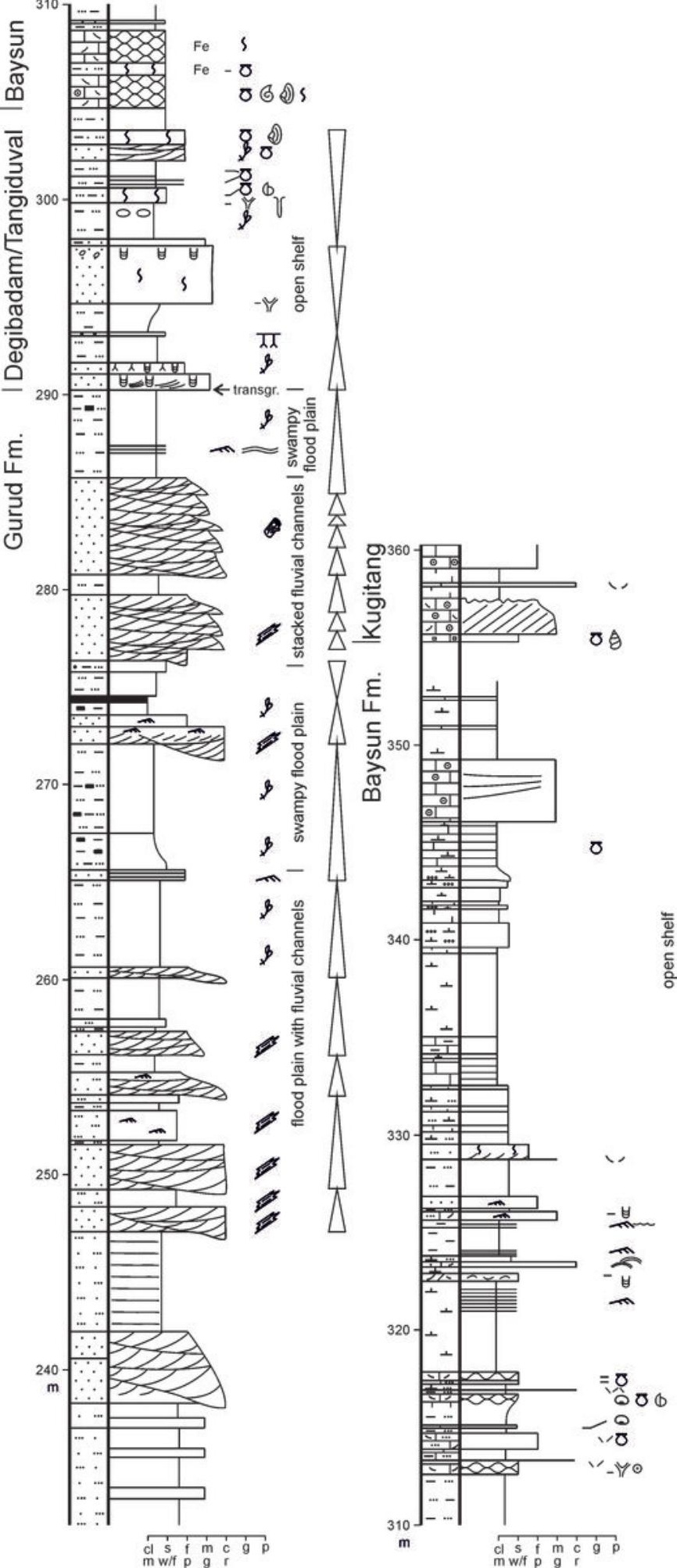




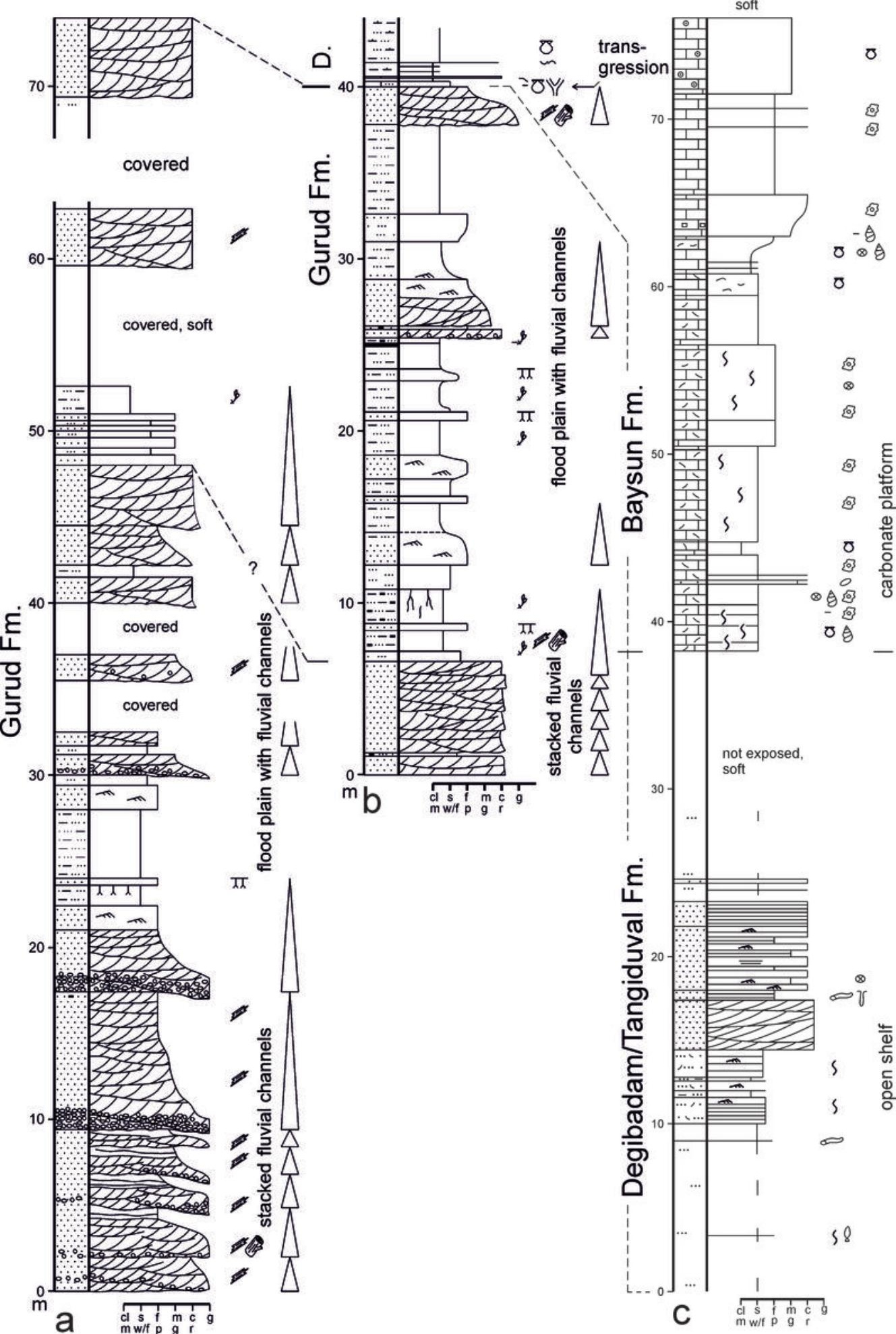




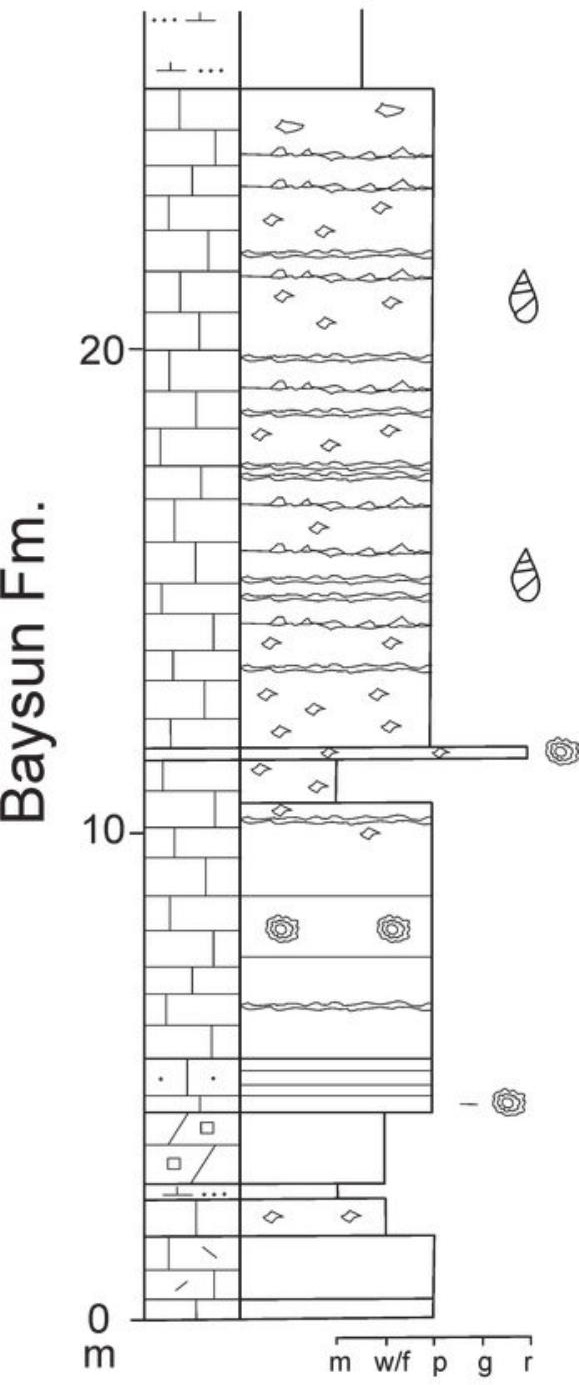

algal lamination

$\diamond \diamond$ birdseyes

$\curvearrowright$ fenestral fabrics 



\section{Depositional cycles (c-j: parasequences)}
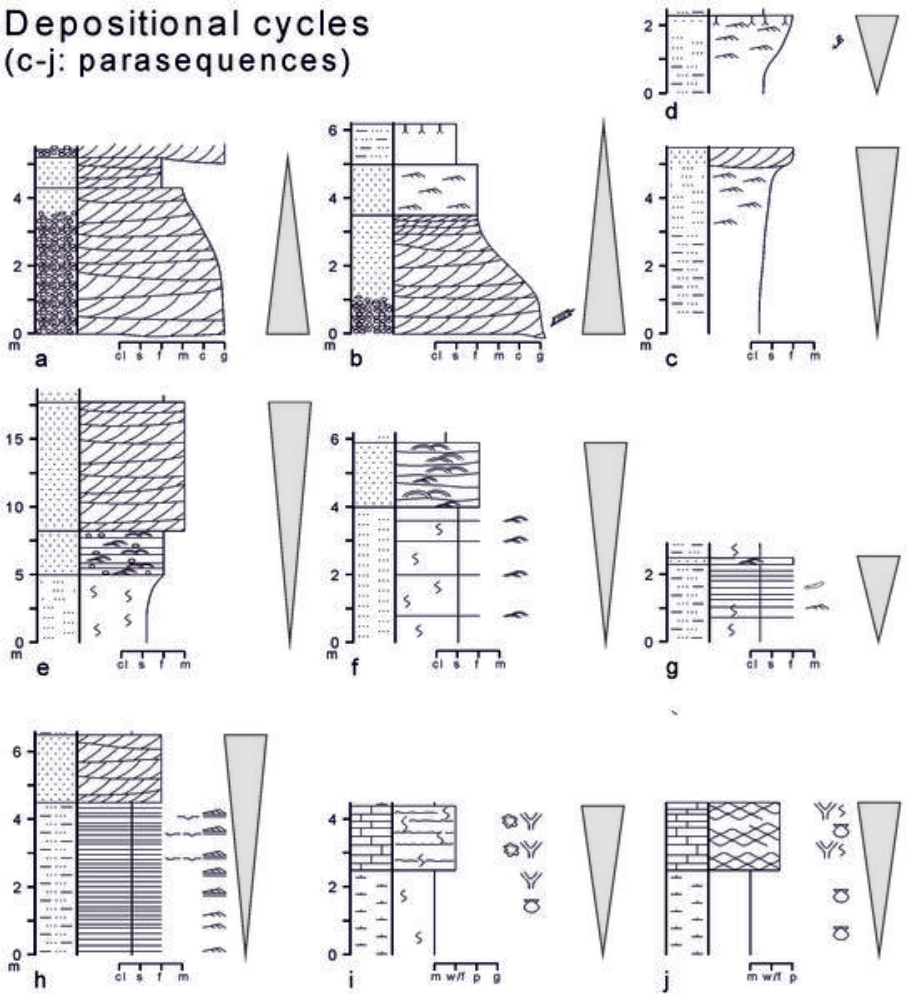


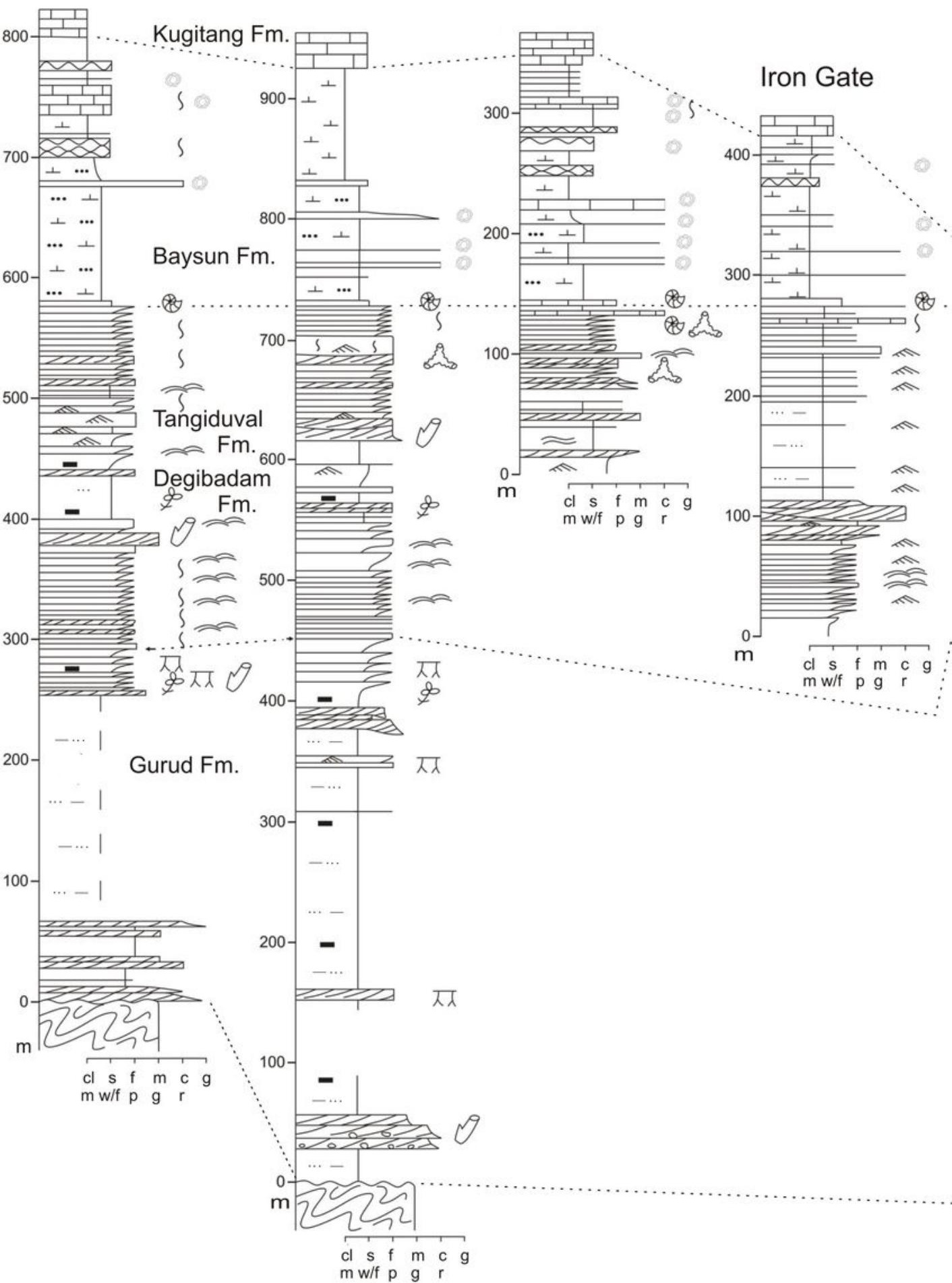




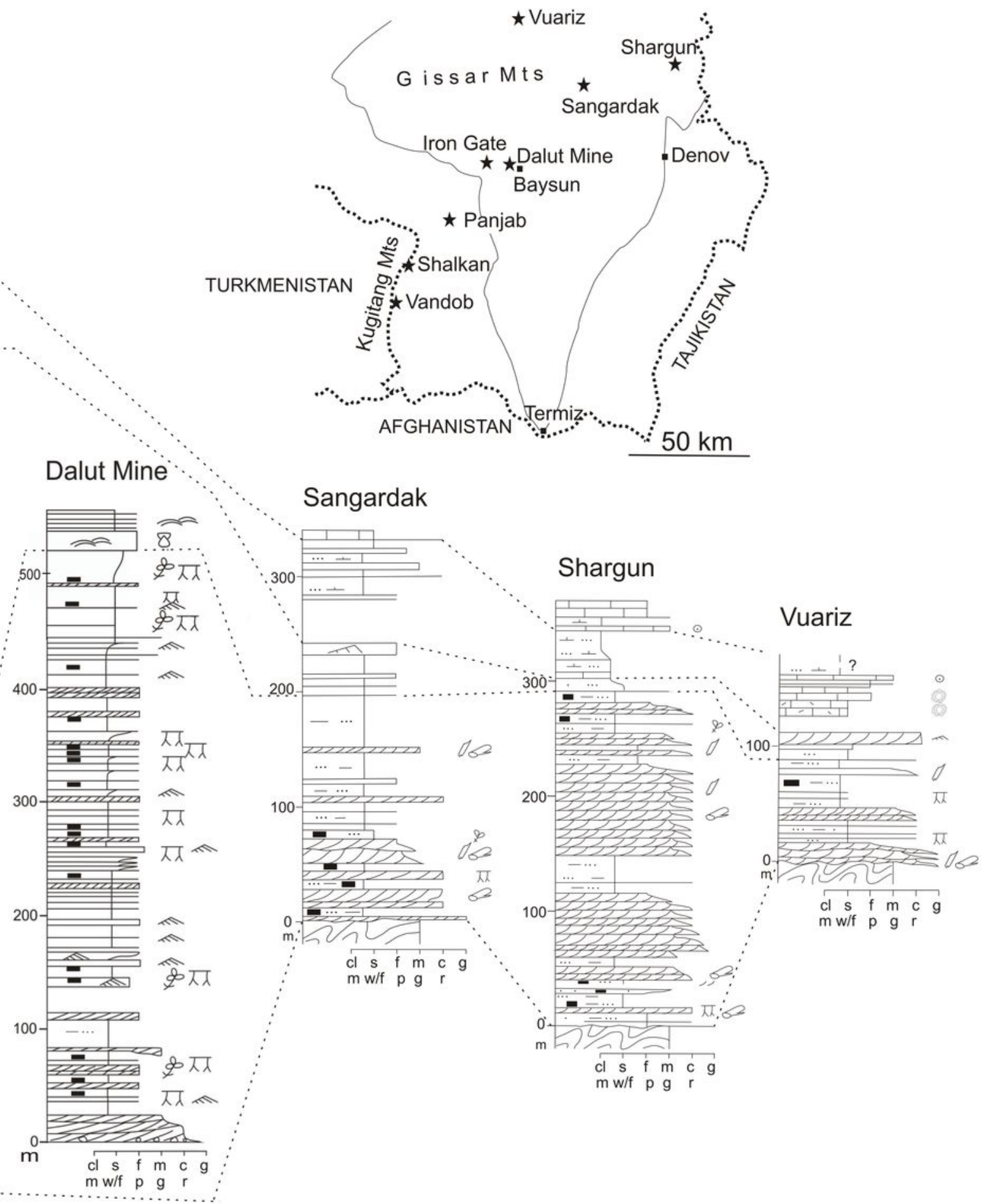




\section{Kugitang Fm.}

Baysun Fm.

\section{Tangiduval Fm.}

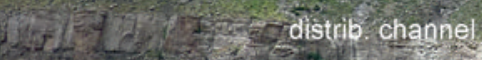
Degibadam Fm:

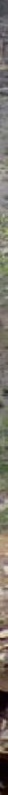

\section{low-energy}

carbonate ramp 
Table 2

\begin{tabular}{|c|c|c|c|}
\hline $\begin{array}{c}\text { Continental } \\
\text { palaeoenvironments }\end{array}$ & $\begin{array}{c}\text { lithology } \\
\text { (facies associations) } \\
\end{array}$ & sedimentary structures & fossils/trace fossils \\
\hline $\begin{array}{l}\text { braided river } \\
\text { channels }\end{array}$ & $\begin{array}{l}\text { fine- to coarse-grained } \\
\text { arkosic or quartz-rich ss, } \\
\text { partly gravely to } \\
\text { conglomeratic, immature }\end{array}$ & $\begin{array}{l}\text { large-scale trough cross- } \\
\text { bedding, erosional base, } \\
\text { fining-upward, vertical } \\
\text { stacking common }\end{array}$ & wood fragments, tree trunks \\
\hline $\begin{array}{l}\text { meandering river } \\
\text { channels with levee } \\
\text { deposits }\end{array}$ & $\begin{array}{l}\text { fine-grained ss, partly } \\
\text { silty, moderately to well } \\
\text { sorted; levee deposits: } \\
\text { interbedded fine-grained } \\
\text { ss and silty clay }\end{array}$ & $\begin{array}{l}\text { lateral accretion, large- } \\
\text { scale trough cross- } \\
\text { bedding, ripple } \\
\text { lamination, erosional } \\
\text { base, fining-upward }\end{array}$ & plant fragments, rootlets \\
\hline $\begin{array}{l}\text { flood plain with } \\
\text { crevasse splays }\end{array}$ & $\begin{array}{l}\text { silty clay to argillaceous } \\
\text { silt with cm- to dm-thick, } \\
\text { sharp-based fine-grained } \\
\text { ss and siltstone } \\
\text { intercalations, partly } \\
\text { lenticular }\end{array}$ & $\begin{array}{l}\text { current ripple lamination, } \\
\text { rootlets, }\end{array}$ & plant fragments common \\
\hline $\begin{array}{l}\text { flood plain with } \\
\text { palaeosol }\end{array}$ & $\begin{array}{l}\text { (a) ferruginous fine-sandy } \\
\text { silt } \\
\text { (b) brown clay with } \\
\text { scattered quartz granules }\end{array}$ & & (a) rootlets \\
\hline $\begin{array}{l}\text { floodplain swamp, } \\
\text { swampy lake margin }\end{array}$ & $\begin{array}{l}\text { coal, strongly } \\
\text { carbonaceous clay or silty } \\
\text { clay }\end{array}$ & & rich in plant debris \\
\hline lake margin & $\begin{array}{l}\text { fine-grained ss, siltstone, } \\
\text { coarsening-upward }\end{array}$ & $\begin{array}{l}\text { ripple lamination, top } \\
\text { occasionally rooted }\end{array}$ & plant debris common \\
\hline lacustrine delta & $\begin{array}{l}\text { coarsening-upward } \\
\text { succession of silty clay to } \\
\text { thin-bedded fine-sandy } \\
\text { silt or fine-grained } \\
\text { sandstone }\end{array}$ & $\begin{array}{l}\text { coarser layers with ripple } \\
\text { lamination, top bed in } \\
\text { some cases with large- } \\
\text { scale trough stratification } \\
\text { and erosional base }\end{array}$ & plant debris common \\
\hline $\begin{array}{l}\text { storm-influenced } \\
\text { lake }\end{array}$ & $\begin{array}{l}\text { argillaceous silt with cm- } \\
\text { scale fine-grained ss } \\
\text { intercalations }\end{array}$ & $\begin{array}{l}\text { ss parallel- or ripple- } \\
\text { laminated, with sharp } \\
\text { base; some with HCS }\end{array}$ & plant fragments common \\
\hline $\begin{array}{l}\text { low-energy offshore } \\
\text { lake }\end{array}$ & $\begin{array}{l}\text { argillaceous silt to silty } \\
\text { clay, partly with } \\
\text { claystone concretions, } \\
\text { rarely silty micrite }\end{array}$ & $\begin{array}{l}\text { partly shaly, partly } \\
\text { bioturbated }\end{array}$ & plant debris common \\
\hline \multicolumn{4}{|l|}{$\begin{array}{c}\text { Marine } \\
\text { palaeoenvironments }\end{array}$} \\
\hline distributary channel & $\begin{array}{l}\text { medium- to coarse- } \\
\text { grained immature ss }\end{array}$ & $\begin{array}{l}\text { base sharp, erosional, } \\
\text { fining-upward, large-scale } \\
\text { trough cross-stratification, } \\
\text { top ripple-laminated }\end{array}$ & wood pieces common \\
\hline $\begin{array}{l}\text { protected } \\
\text { embayment }\end{array}$ & $\begin{array}{l}\text { fine-sandy silty clay, } \\
\text { locally carbonaceous; silt, }\end{array}$ & $\begin{array}{l}\text { bioturbated; silt } \\
\text { commonly ripple- }\end{array}$ & plant debris \\
\hline
\end{tabular}




\begin{tabular}{|c|c|c|c|}
\hline & $\begin{array}{l}\text { fine-sandy silt, with } \\
\text { occasional cm- to dm- } \\
\text { thick fine-grained ss } \\
\text { intercalations }\end{array}$ & $\begin{array}{l}\text { laminated } \\
\text { ss commonly parallel- } \\
\text { laminated }\end{array}$ & \\
\hline delta front & $\begin{array}{l}\text { arkosic fine- to medium- } \\
\text { grained ss }\end{array}$ & $\begin{array}{l}\text { ripple-lamination, low- } \\
\text { angle large-scale trough } \\
\text { cross-stratification, } \\
\text { coarsening-upward }\end{array}$ & $\begin{array}{l}\text { wood pieces, thin bioturbated } \\
\text { intervals (Thalassinoides) }\end{array}$ \\
\hline prodelta & $\begin{array}{l}\text { argillaceous silt with } \\
\text { occasional cm-thick fine- } \\
\text { grained ss interbeds }\end{array}$ & $\begin{array}{l}\text { ss ripple-laminated, } \\
\text { argillaceous silt } \\
\text { bioturbated }\end{array}$ & ammonites \\
\hline $\begin{array}{l}\text { tide-influenced inner } \\
\text { siliciclastic ramp }\end{array}$ & $\begin{array}{l}\text { interlayered bedding of } \\
\text { fine-grained ss }(0.5-5 \mathrm{~cm}) \\
\text { and argillaceous silt }(1-2 \\
\mathrm{cm}) \text {; } \\
\text { fine-grained sandstone }\end{array}$ & $\begin{array}{l}\text { ss ripple-laminated; } \\
\text { flaser-bedding, lenticular } \\
\text { bedding, oscillation } \\
\text { ripples }\end{array}$ & Gyrochorte \\
\hline $\begin{array}{l}\text { high-energy inner } \\
\text { carbonate ramp }\end{array}$ & $\begin{array}{l}\text { m-thick bio-oo- } \\
\text { grainstone }\end{array}$ & $\begin{array}{l}\text { large-scale planar cross- } \\
\text { bedding, sharp base }\end{array}$ & \\
\hline $\begin{array}{l}\text { low-energy lagoonal } \\
\text { intertidal carbonate } \\
\text { flats }\end{array}$ & $\begin{array}{l}\text { carbonate mudstones and } \\
\text { fine-grained packstones }\end{array}$ & $\begin{array}{l}\text { birdseyes and laminoid } \\
\text { fenestral fabric, thin, } \\
\text { irregular algal laminae }\end{array}$ & scattered gastropods \\
\hline $\begin{array}{l}\text { submarine dunes of } \\
\text { the inner to middle } \\
\text { siliciclastic ramp }\end{array}$ & $\begin{array}{l}\text { dm- to m-thick fine- to } \\
\text { medium-grained ss, } \\
\text { partly bioclastic }\end{array}$ & $\begin{array}{l}\text { large-scale trough cross- } \\
\text { bedding }\end{array}$ & $\begin{array}{l}\text { disarticulated bivalves, crinoid } \\
\text { ossicles, Ophiomorpha }\end{array}$ \\
\hline $\begin{array}{l}\text { storm-wave } \\
\text { influenced middle } \\
\text { siliciclastic ramp }\end{array}$ & $\begin{array}{l}\text { argillaceous to fine-sandy } \\
\text { silt with intercalations of } \\
\text { dm- to m-thick fine- } \\
\text { grained ss }\end{array}$ & $\begin{array}{l}\text { ss with hummocky cross- } \\
\text { stratification and sharp } \\
\text { base; beds partly } \\
\text { amalgamated; fine- } \\
\text { grained sediments } \\
\text { bioturbated }\end{array}$ & Thalassinoides, Skolithos \\
\hline $\begin{array}{l}\text { storm-flow } \\
\text { influenced outer } \\
\text { siliciclastic ramp }\end{array}$ & $\begin{array}{l}\text { argillaceous silt with cm- } \\
\text { thick well sorted, fine- } \\
\text { grained ss intercalations }\end{array}$ & $\begin{array}{l}\text { ss with sharp, erosional } \\
\text { base, either parallel- } \\
\text { laminated, ripple- } \\
\text { laminated or developed as } \\
\text { couplets; partly with } \\
\text { gutter casts, flute casts, } \\
\text { tool marks; } \\
\text { argillaceous silt } \\
\text { bioturbated }\end{array}$ & $\begin{array}{l}\text { Thalassinoides, Planolites, } \\
\text { Chondrites, Rhizocorallium } \\
\text { irregulare, wood fragments } \\
\text { scattered bivalves; shell } \\
\text { concentrations as fills of gutter } \\
\text { casts }\end{array}$ \\
\hline $\begin{array}{l}\text { low-energy mixed } \\
\text { carbonate- } \\
\text { siliciclastic outer } \\
\text { ramp }\end{array}$ & silty marl, marly silt, & $\begin{array}{l}\text { bioturbated, loosely } \\
\text { packed shell } \\
\text { concentrations, }\end{array}$ & $\begin{array}{l}\text { small softground fauna (e.g., } \\
\text { the bivalves Corbulomima, } \\
\text { Nicaniella), Arcomytilus, } \\
\text { Integricardium, Ph. } \\
\text { (Bucardiomya), Plagiostoma, } \\
\text { Chlamys) }\end{array}$ \\
\hline $\begin{array}{l}\text { low-energy } \\
\text { carbonate outer ramp }\end{array}$ & $\begin{array}{l}\text { marl, marlstone, } \\
\text { biofloatstone, oncofloat- } \\
\text { /rudstone, biowackestone }\end{array}$ & $\begin{array}{l}\text { bioturbated, partly with } \\
\text { nodular texture }\end{array}$ & $\begin{array}{l}\text { ammonites (rare) } \\
\text { occasional bivalves (e.g., } \\
\text { Plagiostoma) }\end{array}$ \\
\hline $\begin{array}{l}\text { condensed mixed } \\
\text { carbonate- } \\
\text { siliciclastic outer } \\
\text { ramp }\end{array}$ & $\begin{array}{l}\text { bioclastic silty to fine- } \\
\text { sandy micrite }\end{array}$ & $\begin{array}{l}\text { highly bioturbated, in } \\
\text { places nodular }\end{array}$ & $\begin{array}{l}\text { ammonites (mainly } \\
\text { Procerites) and bivalves } \\
\text { common (e.g., Entolium, } \\
\text { Bucardiomya, Pleuromya, } \\
\text { Ctenostreon, Liostrea); } \\
\text { brachiopods and gastropods }\end{array}$ \\
\hline
\end{tabular}


\begin{tabular}{|l|l|l|l}
\hline & & (Obornella) occur \\
\hline
\end{tabular} 
Table 1. Section localities

\begin{tabular}{|c|c|c|c|}
\hline 1 & Shalkan, Kugitang Mountains & $\begin{array}{l}\text { N } 37^{\circ} 51^{\prime} 58.5^{\prime \prime} \\
\text { N } 37^{\circ} 52^{\prime} 58.4^{\prime \prime}\end{array}$ & $\begin{array}{l}\text { E } 66^{\circ} 38^{\prime} 06.0^{\prime \prime} \text { (base) } \\
\text { E } 66^{\circ} 38^{\prime} 11.4^{\prime \prime} \text { (top) }\end{array}$ \\
\hline 2 & Vandob, Kugitang Mountains & $\begin{array}{l}\text { N } 37^{\circ} 43^{\prime} 07.9^{\prime \prime} \\
\text { N } 37^{\circ} 43^{\prime} 13.3^{\prime \prime}\end{array}$ & 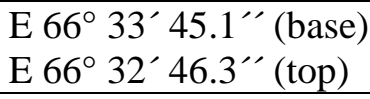 \\
\hline 3 & Panjab, northern Kugitang Mts. & $\mathrm{N} 38^{\circ} 02^{\prime} 07.4^{\prime \prime}$ & E $66^{\circ} 49^{\prime} 44.1^{\prime \prime}$ \\
\hline 4 & $\begin{array}{l}\text { Dalut Mine near the village of Toda, } \\
\text { South Gissar Mts. }\end{array}$ & $\mathrm{N} 38^{\circ} 15^{\prime} 09.1^{\prime \prime}$ & E $67^{\circ} 07^{\prime} 36.7^{\prime \prime}$ \\
\hline 5 & $\begin{array}{l}\text { Gorge N of Derbent, southern tip of } \\
\text { Gissar Mts. (Iron Gate) }\end{array}$ & $\mathrm{N} 38^{\circ} 15^{\prime} 35,5^{\prime \prime}$ & E $67^{\circ} 01^{\prime} 34.8^{\prime \prime}$ \\
\hline 6 & $\begin{array}{l}\text { Shargun section, coal mine N of } \\
\text { Shargun, SE Gissar Mts }\end{array}$ & 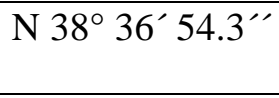 & E $67^{\circ} 57^{\prime} 48.1^{\prime \prime}$ \\
\hline 7 & Sangardak, SE Gissar Mts. & $\mathrm{N} 38^{\circ} 31^{\prime} 57.9^{\prime \prime}$ & E $67^{\circ} 34^{\prime} 47.4^{\prime \prime}$ \\
\hline 8 & Vuariz section I, ESE of Shahrisabsz & $\mathrm{N} 38^{\circ} 48^{\prime} 41.5^{\prime \prime}$ & E $67^{\circ} 10^{\prime} 04.4^{\prime \prime}$ \\
\hline 9 & Vuariz section II, ESE of Shahrisabsz & $\mathrm{N} 38^{\circ} 48^{\prime} 20.6^{\prime \prime}$ & E $67^{\circ} 10^{\prime} 49.4^{\prime \prime}$ \\
\hline 10 & Vuariz section III, ESE of Shahrisabsz & $\mathrm{N} 38^{\circ} 48^{\prime} 50.3^{\prime \prime}$ & E $67^{\circ} 09^{\prime} 41.9^{\prime \prime}$ \\
\hline 11 & Vuariz section IV, ESE of Shahrisabsz & 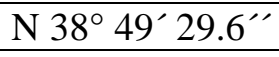 & E $67^{\circ} 11^{\prime} 26.3^{\prime \prime}$ \\
\hline
\end{tabular}

